\title{
A DINÂMICA DA EXECUÇÃO ORÇAMENTÁRIA FEDERAL DO BRASIL SOB A ÓTICA DOS CICLOS POLÍTICOS ELEITORAIS, 1985-2010
}

\author{
Rafael Divino de Vasconcelos * \\ Ś́lvio Ferreira Júnior ${ }^{\dagger}$ \\ Reginaldo Pinto Nogueira Junior $\ddagger$
}

\begin{abstract}
Resumo
Este artigo investiga a existência e a intensidade da relação entre o calendário das eleições presidenciais brasileiras e a dinâmica da execução orçamentária federal, no período de 1985 a 2010, levando em conta as mudanças institucionais nesse período. Concluiu-se que a política fiscal federal apresenta comportamento cíclico, onde as receitas e despesas públicas estão condicionadas, em boa parte, à periodicidade das eleições presidenciais. Foi inconclusivo o efeito da Emenda à Reeleição sobre a condução da política fiscal. Todavia, a Lei de Responsabilidade Fiscal permitiu reduzir as oscilações cíclicas em boa parte das despesas e receitas do orçamento federal.
\end{abstract}

Palavras-chave: Ciclo político; Política fiscal; Orçamento; Eleições; Responsabilidade fiscal; Reeleição.

\begin{abstract}
In this paper we investigate the existence of a relationship between presidential elections in Brazil and the conduct of fiscal policy by the federal government, along the period from 1985 to 2010. We also look at the possible effects of major institutional changes that took place in Brazil over the period, namely the Fiscal Responsibility act and the presidential reelection amendment to the constitution. Overall, we conclude that at the federal level the conduct of fiscal policy behaves cyclically, following the political calendar. The results for the reelection amendment are inconclusive regarding its true importance for the conduct of fiscal policy at the federal level. However, we found an important role for the fiscal responsibility act in reducing annual fluctuations in some revenues and expenditures of the federal budget.
\end{abstract}

Keywords: Political cycle; Fiscal policy; Budget; Elections; Fiscal responsibility; Reelection.

JEL classification: E62, H50, H60

\footnotetext{
* Universidade do Estado de Minas Gerais. E-mail: vasconcelosrd@gmail.com

${ }^{\dagger}$ Fundação João Pinheiro. E-mail: silvio.junior@fjp.mg.gov.br

‡ Instituto Brasileiro de Mercado de Capitais (IBMEC). E-mail: reginaldo.nogueira@ibmecmg.br
} 


\section{Introdução}

Nas décadas de 1970 e 1980, a economia de vários países em todo o mundo conviveu com um quadro de forte desequilíbrio fiscal, decorrente da piora nos níveis de endividamento dos governos, algo que se evidenciou de forma mais aguda nos países subdesenvolvidos (Azevedo 1997). Surgem daí as discussões em torno do papel do Estado, o qual, a despeito da divergência entre as interpretações, passou a existir consenso de que o aparelho estatal deveria ser reestruturado em sua dinâmica interna e em suas relações com a sociedade e o mercado.

No Brasil, os problemas envolvendo déficit público e endividamento vieram a se tornar flagrantes a partir da década de 80 , passando a economia brasileira a conviver com períodos frequentes de baixa credibilidade em sua capacidade de honrar os pagamentos da dívida. Nesse contexto, a criação de mecanismos de controle do déficit público foi ganhando relevância como componente básico para se estabelecer os fundamentos macroeconômicos coerentes com a meta de crescimento econômico sustentado.

Nesse sentido, uma série de reformas estruturais e institucionais passou a ser adotada no país, de maneira incremental e mais intensamente a partir da década de 90, até a aprovação da Lei de Responsabilidade Fiscal (LRF), em maio de 2000. Esta, que pode ser considerada o marco da consolidação da política de austeridade fiscal, estendeu o controle do déficit público às esferas infranacionais e tornou mais efetivas as metas explícitas de resultado primário para o setor público consolidado.

É de se esperar que a institucionalização dos mecanismos de controle possa, além dos efeitos esperados sobre o endividamento público, atenuar possíveis abusos fiscais de caráter eleitoreiro, que dão origem a comportamentos cíclicos nas execuções do orçamento público, também conhecidos como "ciclos políticos eleitorais" ou, mais especificamente, "ciclos políticos orçamentários". O entendimento que prevalece, especialmente nos círculos acadêmicos, é que a responsabilidade fiscal não deve ser colocada em segundo plano em detrimento do oportunismo eleitoral, sob a pena de comprometer a própria capacidade de provisão de bens e serviços públicos em períodos futuros.

Todavia, há de se destacar uma mudança importante no sistema eleitoral brasileiro e que poderia estar atuando como força contrária às mudanças institucionais de fortalecimento da austeridade fiscal: a criação da Emenda Constitucional 16, de 4 de junho de 1997, denominada "Emenda da Reeleição", e que passou a permitir a manutenção de um mesmo governo por até dois mandatos seguidos.

Levanta-se, portanto, a questão sobre até que ponto as motivações para uma reeleição ou demais interesses eleitoreiros teriam efeito sobre a oscilação no nível e na composição dos gastos e das receitas públicas federais, e que poderiam resultar numa gestão incoerente com a sua situação fiscal ou destoante da lista de prioridades socialmente ótimas. No que tange à LRF, a hipótese que pode ser levantada é de que essa legislação se mostra mais incisiva sobre a conduta fiscal dos estados e municípios, de modo que sua criação não teria provocado alterações tão significativas no comportamento cíclico eleitoral do gasto público federal.

Diante do exposto, entende-se ser pertinente analisar possíveis comportamentos cíclicos de motivaçã o político-eleitoral para a execução orçamentária no Brasil. A análise das principais variações na receita e no gasto público que 
prevalecem durante os períodos próximos às eleições é útil para se perceber o grau de comprometimento dos políticos em relação às metas da política fiscal.

Assim, este artigo tem por objetivo estudar o comportamento da execução orçamentária federal no período de 1985 a 2010, analisando, em particular, os efeitos de mudanças institucionais recentes (LRF e a Emenda à Reeleição), sob a ótica dos ciclos políticos eleitorais. Por meio de uma abordagem econométrica, pretende-se identificar a existência de uma relação sistemática entre a proximidade das eleições presidenciais e as variações nas principais contas de receita e de despesa registradas nas execuções do orçamento federal.

De forma geral, foi possível concluir, que, no nível federal, a política fiscal reflete um comportamento cíclico, orientado por interesses eleitorais, que fazem com que o comportamento temporal das receitas e despesas públicas fique condicionado à periodicidade das eleições presidenciais. Do lado das receitas, constata-se, por exemplo, que, para o período analisado, as receitas totais são menores em períodos pré-eleitorais e expressivamente maiores em períodos eleitorais, enquanto que os empréstimos (operações de crédito) são maiores nos anos pré-eleição, eleição e pós-eleição, com aumentos a taxas crescentes de um período a outro. Do lado das despesas, percebe-se que, em anos eleitorais, são maiores os gastos na "educação e cultura" e na "assistência e previdência". Por sua vez, as despesas com "transporte", são maiores em anos pré-eleitorais e menores nos anos seguintes. Os resultados para a Emenda à Reeleição foram inconclusivos quanto a sua verdadeira relevância para a manipulação da política fiscal. Por outro lado, evidenciou-se o importante papel da LRF na edução de ciclos eleitorais em algumas despesas e receitas executadas no orçam nto federal.

Este artigo compõe-se de 5 seções, incluindo esta introdução. Na seguinte, desenvolve-se uma revisão teórica da evolução dos modelos de ciclos políticos eleitorais. Na terceira seção, aborda-se o referencial metodológico e o modelo utilizado. A discussão dos resultados do modelo será realizada na seção 4 , para que finalmente, na seção 5 , sejam apresentadas as conclusões gerais.

\section{Revisão da Literatura}

A literatura permite classificar quatro categorias de ciclos: Ciclos eleitorais oportunistas (Political Business Cycles - PBC); Ciclos eleitorais oportunistas racionais (Rational Political Business Cycles - RPBC); Ciclos partidários (Partisan Theory - PT); e Ciclos partidários racionais (Rational Partisan Theory RPT).

A teoria de ciclos políticos eleitorais vem se desenvolvendo concomitantemente aos avanços da macroeconomia geral. Na década de 1970, era norteada pelo pressuposto das expectativas adaptativas, segundo o qual os agentes econômicos formam suas expectativas sem levar em consideração toda a informação disponível, ajustando suas previsões parcialmente a cada período. Contextualizando, os eleitores são "míopes"; ou seja, podem ser sistematicamente enganados pelos políticos. A referência é Nordhaus (1975) ao instituir a teoria intitulada como "Political Business Cycles" (Ciclos Políticos de Negócios), também reconhecida na literatura acadêmica como "modelo PBC", ou ciclos eleitorais oportunistas. A hipótese do autor é de que os políticos agem constantemente em busca do seu principal objetivo: alcançar a maximização de votos tendo em vista um desempenho vitorioso nas próximas eleições. Para 
isso, interferem no trade-off da curva de Phillips, aproveitando-se da dificuldade do eleitor enxergar o passado.

Outra vertente dessa literatura são os "modelos de ciclos partidários" (Partisan Theory, "PT"), ou "modelos de ciclos ideológicos". Iniciados por Hibbs Júnior (1977), também com base em expectativas adaptativas, abordam o tradeoff entre desemprego e inflação, mas introduzem a importância da ideologia de cada partido para as políticas. Esclarecemos que essa vertente não será analisada em nossa análise empírica devido à grande dificuldade de se definir claramente a ideologia partidária no Brasil. Além disso, embora trabalhos como Sakurai (2009) tenham demonstrado algum papel para a ideologia partidária, outros, como Nakaguma \& Bender (2006), indicaram que a ideologia partidária não parece causar interferência significativa nos ciclos políticos orçamentários para o caso brasileiro.

Ainda no final da década de 1970, concomitantemente ao desenvolvimento da teoria macroeconômica, foram ganhando força os modelos que consideravam a tomada de decisão dos agentes a partir da formação de expectativas racionais. Sargent \& Wallace (1975) foram precursores dessa abordagem, colocando em dúvida os resultados encontrados por Nordhaus (1975). Em um teste empírico para as eleições presidenciais americanas no período de 1948 a 1974 , os autores sugerem que os eleitores não podem ser enganados sistematicamente, pois conseguem ter a visão de todo o ambiente político e econômico (sem necessariamente conhecer com perfeição as ações e intenções dos governos) e se antecipam às manipulações oportunistas na economia de forma a anular seus efeitos. O resultado disso é a perspectiva de ciclos mais curtos e menos frequentes.

No entanto, existe uma assimetria de informação temporária a respeito da competência dos governantes no período $t$. É essa diferença temporária quanto à informação disponível que ainda viabiliza manobras oportunistas na economia e permite a existência de ciclos, mesmo tendo como pressuposto as expectativas racionais (Rogoff \& Silbert 1988).

Logo, a competência de um político só pode ser atestada de fato pelo eleitor com certa defasagem de tempo. Assim, os governantes sinalizam maior competência nos períodos pré-eleitorais, normalmente através de políticas visíveis como: aumento de transferências, maior provisão de bens públicos e serviços, redução de impostos ou dos preços regulados e expansão monetária.

Os trabalhos de Rogoff \& Silbert (1988) e Rogoff (1990) estão entre as referências mais destacadas na literatura, especialmente quando se trata de ciclos políticos orçamentários baseados em expectativas racionais. No período préeleitoral prevalecem a redução de impostos e a prática abusiva de emissão monetária, enquanto no período pós-eleitoral o resultado comum é inflação e aumento da dívida.

Rogoff (1990) introduz a ideia de que a expansão dos gastos é priorizada para os itens de maior visibilidade ao eleitorado em detrimento do investimento. Sob a concepção do oportunismo eleitoral, isso se justifica, pois o investimento, pressupõe o autor, conta com um prazo de maturação e realização até que se torne visível ao eleitor no período $t+1$. Já alguns gastos públicos que propiciam o consumo rápido de bens e serviços podem ser percebidos no período $t$. Portanto, o ciclo político orçamentário típico direciona a política fiscal no ano eleitoral para gastos em bens e serviços cuja provisão governamental é imediata e visível, enquanto reduz os gastos em investimentos cujos 
prazos para conclusão são demorados, dificultando a imediata visibilidade dos benefícios por parte de seus eleitores.

No sentido acima exposto Drazem \& Eslava (2005) evidenciaram que, para o caso das municipalidades colombianas, os políticos em períodos que antecedem as eleições tentam sinalizar preferências idênticas aos eleitores, ao realocar maior parcela do gasto para itens mais visíveis e atrativos, normalmente relacionados à infraestrutura. Na mesma direção, Veiga \& Veiga (2007) identificaram comportamento semelhante ao estudar o caso de municipalidades portuguesas. Conforme esperado pela teoria RPBC, os autores perceberam uma tentativa dos políticos de sinalizar competência, favorecendo em períodos pré-eleitorais itens de despesa de alta visibilidade para os eleitores.

Outros trabalhos empíricos mais recentes justificam o esforço desta pesquisa em buscar uma relação entre a evolução institucional no Brasil e a interferência oportunista dos políticos nos gastos públicos. Esses trabalhos, de modo geral, vêm tentando relacionar a amplitude dos ciclos observados ao nível de desenvolvimento dos países.

Brender \& Drazen (2004) evidenciaram que a manipulação na política fiscal de viés eleitoral tende a ser maior quanto mais jovem for uma democracia. Shi \& Svensson (2006) constataram que os ciclos orçament rios são mais frequentes em países subdesenvolvidos, possivelmente, po possuírem arranjos institucionais mais frágeis e flexíveis para manobras no campo fiscal. ${ }^{1}$

Nakaguma \& Bender (2006) propuseram-se a analisar a existência de ciclos políticos orçamentários para os estados brasileiros no período de 1986 a 2002 e, especialmente, evidenciar possíveis diferenças na intensidade das manobras de cunho oportunista-eleitoreiro sobre os instrumentos fiscais antes e depois da Lei de Responsabilidade Fiscal e da Emenda à Reeleição.

O escopo de análise do trabalho referenciado foi bastante amplo, contemplando, por exemplo, a evidência de ciclos no resultado orçamentário, a partir da constatação de elevação dos déficits no período eleitoral. Os resultados sobre as receitas foram esmiuçados por categorias de receitas, como corrente, de capital e operações de crédito, além da receita total. De modo geral, verificouse a existência de ciclos em todas elas. No âmbito das despesas, analisadas sob as óticas da categoria econômica e da funcional, constataram que os políticos brasileiros "atuam oportunamente, concentrando os gastos nos setores mais "rentáveis" em termos de votos".

Quanto à influência da Emenda à Reeleição, constatou-se que ela contribui para aguçar os ciclos políticos orçamentários, enquanto a Lei de Responsabilidade Fiscal se mostrou uma peça importante para fins de controle do endividamento e melhora do gasto público, haja vista as contribuições efetivas para a redução das despesas de custeio. ${ }^{2}$

Em análise sobre as eleições presidenciais brasileiras no período pós- redemocratização, de 1985 a 2006, Salvato et al. (2008) perceberam um comportamento oportunista ao evidenciarem expansões econômicas nos períodos pré-eleitorais. Os autores identificaram um padrão cíclico de queda do gasto público no período pós-eleitoral, de forma a reduzir as pressões inflacionárias amplificadas no período anterior. Tais resultados, todavia, são restritos

\footnotetext{
${ }^{1}$ No mesmo sentido, Streb et al. (2009) verificaram que países desenvolvidos não apresentam de modo geral, comportamento cíclico nos gastos, enquanto países em desenvolvimen o (ou novas democracias), por terem ainda fracas restrições institucionais, estão mais sujeitos a esse fenômeno.

${ }^{2}$ Ver Queiroz (2009), em análise para gestões estaduais do Ceará no período de 1986 a 2006.
} 
ao montante do gasto público total, ao passo que a nossa proposta também se ocupa da manipulação oportunista da composição desse gasto, na medida em que desmembra e analisa as despesas orçamentárias por categoria econômica e sob a ótica funcional.

Recorrendo ao modelo de reputação política, ${ }^{3}$ Novaes (2007) chega a resultados interessantes, que sinalizam um comportamento cíclico nos gastos públicos municipais para a área da saúde, especialmente quando prefeitos estão motivados pela possibilidade de reeleição. Sakurai (2009), em ampla análise envolvendo 5.506 municípios brasileiros para o período de 1987 a 2000, constatou que algumas funções do gasto, como "Saúde e Saneamento", "Assistência e Previdência", "Habitação e Urbanismo" e "Transporte", por possuírem maior visibilidade de seus benefícios perante a população, acabam sendo priorizadas com maior volume de recursos no ano eleitoral, enquanto em outras áreas, como "Educação e Cultura", não se percebem manipulações eleitorais ou mesmo verifica-se tendência de corte nos gastos, como é o caso das funções "Legislativa" e "Agricultura".

Quanto aos possíveis efeitos da LRF nas contas municipais, Sakurai (2009) evidencia que essa legislação contribui para o que chama de "efeito composição", o qual reflete uma tendência geral de concentração de recursos em certas funções cujas despesas são, basicamente, de natureza corrente ("Saúde e Saneamento", "Assistência e Previdência" e "Educação e Cultura"). Por outro lado, percebe-se queda de recursos destinados a funções compostas majoritariamente por investimento, como "Habitação e Urbanismo" e "Transporte".

\section{Metodologia}

\subsection{O modelo SUR - Seemingly Unrelated Regressions}

O modelo utilizado neste trabalho consiste num sistema de equações aparentemente não correlacionadas, também conhecido como modelo SUR (Seemingly Unrelated Regressions). Três características principais do modelo SUR podem ser destacadas, de modo a traduzir sua especificidade e aplicabilidade.

A primeira delas é que o modelo SUR pode ser utilizado para diferentes combinações alternativas de dados, a depender dos objetivos do estudo. Em uma delas, o modelo combina dados de séries temporais e dados de corte transversal, sendo que cada equação do sistema corresponde a um indivíduo, ou entidade, enquanto que os parâmetros de resposta, bem como o intercepto, são específicos para cada indivíduo e constantes no tempo. Outro exemplo de combinação, citado por Wooldridge (2002), consiste num sistema de diferentes equações para diferentes conjuntos de indivíduos e para um único período de tempo, como nos casos em que se pretenda estimar as equações de demanda por alimento, vestuário e habitação. ${ }^{4}$

Uma segunda característica específica do modelo SUR é o fato de que cada equação do sistema corresponde a um único indivíduo (ou grupo de indivíduos), não exigindo que as equações tenham os mesmos valores dos seus parâmetros, nem tampouco exigindo que elas tenham o mesmo número de regressores. Dessa forma, o modelo SUR possibilita detectar as especificidades

\footnotetext{
${ }^{3}$ Ver Novaes (2007) para algumas referências

${ }^{4}$ Para o leitor interessado em conhecer outras combinações alternativas do modelo SUR, alguns estudos no Brasil podem ser citados: Coronel \& Amorim (2010), Fernandes \& Giglio (2009), Ferreira Júnior \& Teixeira (2005) e Costa Júnior \& Neves (2000).
} 
de cada indivíduo, no que tange à sua resposta em relação aos regressores comuns, bem como aos regressores específicos (estes quando houver). ${ }^{5}$

A terceira propriedade específica do modelo SUR está na hipótese de que o termo de erro de pelo menos uma das equações está correlacionado com os termos de erros das demais equações do sistema (correlação contemporânea dos erros). Nos casos em que esta hipótese não é rejeitada, a estimação separada de cada equação, pelo método dos mínimos quadrados ordinários, continua sendo consistente e não viesada, mas os parâmetros perdem eficiência, justamente por não considerar a informação sobre a correlação mútua dos termos de erro da regressão (Greene 1997, Hill et al. 2000). ${ }^{6}$

O modelo SUR se estabelece, em síntese, sob as seguintes pressuposições: i) todos os erros têm média zero; ii) em cada equação do sistema, a variância do erro é constante (não varia com $t$ ), mas pode diferir entre elas; iii) os erros em diferentes períodos de tempo são não correlacionados, sejam eles na mesma equação ou entre as equações sistema (ausência de autocorrelação serial); e, iv) dois erros em diferentes equações, mas no mesmo período de tempo, são correlacionados (presença de correlação contemporânea).

A explicação para ocorrência de correlação contemporânea decorre da existência de situações em que indivíduos ou unidades distintas, por estarem inseridos no mesmo contexto conjuntural (seja de ordem social, econômica, financeira, natural, ou todas elas combinadas), são influenciados por fatores condicionantes comuns, que, quando omitidos das equações do sistema (por impossibilidade de mensuração ou ausência de dados) passam a fazer parte dos erros de cada uma dessas equações, de tal modo que esses erros apresentam-se correlacionados no mesmo período de tempo.

Para o caso específico do presente estudo, a hipótese da correlação contemporânea pode ser justificada não apenas pelo fato de as diferentes contas de receitas e de despesas estarem contabilmente relacionadas, ${ }^{7}$ mas também por elas estarem inseridas num mesmo contexto macroeconômico, financeiro e político. Contexto, este, onde a evolução de uma conta está diretamente ou inversamente relacionada (em maior ou menor grau) ao comportamento de outra(s) conta(s), e vice-versa.

A estimação dos parâmetros no modelo SUR é realizada pelo Método de Zellner, que segue três passos seguintes, conforme detalhados em Griffths et al. (1993) e Greene (1997): a) estima-se separadamente cada equação, por mínimos quadrados ordinários; b) utilizam-se os resíduos das equações ajustadas no passo anterior para estimar a matriz $\sum$ de variância e covariância dos erros das equações; c) reestima-se conjuntamente as equações do sistema, por mínimos quadrados generalizados, utilizando as informações em $\Sigma$.

A informação adicional proporcionada pela correlação contemporânea entre os erros das equações faz com que a estimação conjunta dessas equações,

\footnotetext{
${ }^{5}$ Esta propriedade pode ser considerada uma vantagem do modelo SUR em relação aos modelos mais conhecidos, como os de efeitos fixos (EF) e de efeitos aleatórios (EA), que supõem que apenas o intercepto varia entre os indivíduos, sendo os parâmetros resposta iguais para todos eles (Griffths et al. 1993).

${ }^{6} \mathrm{Na}$ existência de correlação contemporânea, haverá somente uma única situação em que a estimação separada de mínimos quadrados de cada equação será tão eficiente quanto à estimação pela técnica do SUR: quando cada equação do sistema apresentar as mesmas variáveis explicativas e contiver as mesmas observações sobre elas (Hill et al. 2000).

${ }^{7}$ A título de exemplo, "Pessoal e Encargos Sociais" e "Juros e Encargos da Dívida" fazem parte da "Despesa Corrente"; "Amortização da Dívida" e "Investimentos" fazem parte da "Despesa de Capital"; "Despesa Corrente" mais "Despesa de Capital" é igual à "Despesa Total".
} 
pelo método de mínimos quadrados generalizados, gere parâmetros mais precisos, em relação à estimação separada de cada equação, pelo método usual de mínimos quadrados ordinários.

\subsection{Especificação do modelo SUR para análise dos ciclos políticos-orçamentários}

Para a análise de ciclos políticos orçamentários na esfera federal, o modelo SUR foi aplicado a um conjunto de dados de séries temporais onde cada equação corresponde a um grupo de receitas e de despesa do orçamento fiscal e da seguridade social, conforme a seguinte especificação geral:

$$
\begin{aligned}
Y_{i t}= & \beta_{1}+\beta_{2} y_{i t-1}+\beta_{p r e} P R E_{i t}+\beta_{e l e} E L E_{i t}+\beta_{p o s} P O S_{i t}+ \\
& \beta_{6} E R_{i t}+\beta_{7} L R F_{i t}+\beta_{8} P I B_{i t}+\beta_{9} T R E N D_{i}+\varepsilon_{i t}
\end{aligned}
$$

em que: $t=1985, \ldots, 2010 ; i=1, \ldots, n$ representa cada equação de receita ou de despesa no sistema de equações SUR; $Y_{i t}$ é a variável dependente, expressada pelo logaritmo natural da receita e/ou despesa per capita, $Y_{i t-1}$ é a variável dependente defasada em um período; $P R E_{i t}, E L E_{i t}, P O S_{i t}$ são as dummies dos períodos pré-eleitoral, eleitoral e pós-eleitoral, respectivamente; $E R_{i t}$ é a dummy discriminadora do período da emenda da reeleição; $L R F_{i t}$, é a dummy para o período da Lei de Responsabilidade Fiscal.

Com a inclusão de $Y_{i t-1}$ pretende-se detectar a dinâmica do comportamento de cada receita/despesa, ou seja, o modo como as execuções realizadas no período anterior impactam as execuções no instante $t$. As outras duas variáveis de controle são: o PIB, expresso pelo logaritmo natural do produto interno bruto per capita e representando as condições macroeconômicas no instante $t$; e TREND, representando a tendência de longo prazo da variável $Y_{i t}$ no período 1985-2010. A inclusão dessas variáveis contribui para evitar a obtenção de estimativas espúrias ou viesadas para as dummies do modelo.

Com a especificação geral dada pela equação (1), pretende-se captar o efeito das mudanças institucionais sobre os ciclos políticos-eleitorais: a primeira vertente de mudanças é representada pela LRF, voltada a fortalecer o equilíbrio fiscal e reduzir a discricionariedade dos políticos; a segunda vertente é representada pela emenda da reeleição, que, em princípio, estimularia a ocorrência de manipulações oportunistas sobre o orçamento com objetivos eleitoreiros.

A importância de se utilizar três dummies para representar todo o ciclo político eleitoral está no fato de os políticos poderem aumentar os gastos desse período de duas formas diferente, em relação ao chamado ciclo convencional (que prevê o pico de aumento dos gastos no ano eleitoral, seguido de queda no ano pós-eleitoral), conforme ressaltam Van Dalen \& Swank (1996): a) Na primeira forma, eleva-se o gasto no ano pré-eleitoral, devido à previsão de um prazo de maturação necessário para que o gasto produza bens e serviços visíveis aos eleitores à medida que se aproxima a eleição. Na segunda forma, o político encaminha para aprovação o aumento do gasto no final do seu mandato. Por existir um intervalo temporal para a designação e execução destes gastos, muitas vezes, vê-se uma expansão fiscal no período pós-eleitoral. ${ }^{8}$

\footnotetext{
${ }^{8}$ No período analisado, ocorreram sete eleições presidenciais: a primeira indireta (1985) e todas as demais diretas $(1989,1994,1998,2002,2006$ e 2010).
} 
A dummy $E R_{t}$, que busca captar o efeito da Emenda à Reeleição sobre os ciclos políticos orçamentários, assume valor 1 para os anos em que houve possibilidade de reeleição de um candidato à Presidência, ou seja, 1998 e $2006 .^{9}$ Não se define, a priori, o sinal esperado do parâmetro dessa variável. Contudo, pode ser esperado sinal positivo deste parâmetro, ao menos no lado das despesas, o que estaria refletindo tendência de aumento de gastos nos anos eleitorais em que ocorreram candidaturas a reeleição. Todavia, o escasso número de observações no tempo para esta variável, contribuiu para o reduzido número de significâncias estatísticas, conforme apresentado mais adiante nos resultados dos sistemas SUR.

Quanto à dummy LRF, considerou que esta assume o valor 1 para os anos de 2001 a 2010. Ou seja, a partir da vigência da primeira lei orçamentária anual aprovada após o advento da lei de responsabilidade fiscal. ${ }^{10}$ Compartilha-se com o alerta dado por Nakaguma \& Bender (2006) a respeito do cuidado necessário ao se interpretar os coeficientes desta variável, levando em conta que ela pode estar assumindo peso que não lhe é integralmente devida. Apesar de a LRF representar um marco importante na consolidação do compromisso da política macroeconômica com o ajuste e a austeridade fiscal, é importante ressaltar que, ao longo de toda a década de 90, várias outras normas foram criadas em prol do equilíbrio orçamentário.

Sendo assim, é parcimonioso conceder à dummy da LRF o papel de proxy de todas as outras mudanças institucionais relevantes para o ajuste fiscal e que tornaram-se mais amadurecidas a partir da LRF. Dessa forma, considerando os controles efetuados no modelo, trabalha-se com objetivo mais modesto de, ao menos, detectar a existência de significâncias estatísticas para a dummy LRF.

Durante o processo de definição das variáveis que seriam incluídas na especificação geral do modelo SUR, especificações alternativas foram testadas, sempre levando em conta o princípio da parcimônia, dado o reduzido número de informações temporais disponíveis (26 anos). Uma das especificações incluía interações entre a dummy LRF e as dummies de ciclo eleitoral (PRE, ELE, POS), com o objetivo de verificar se a Lei de Responsabilidade Fiscal teria afetado o ciclo eleitoral. Entretanto, os resultados revelaram-se modestos e pouco significativos, certamente devido ao reduzido número de observações para essas dummies interativas. ${ }^{11}$ Outra especificação incluiu a média anual da taxa real básica de juros da economia como regressora nas equações de despesas referentes a serviços da dívida (juros e encargos, amortizações, despesas de capital). Todavia, seus parâmetros não apresentaram significância estatística, optando-se por excluir esse regressor. ${ }^{12}$

Foram ajustados três sistemas de equações SUR distintas: o primeiro sistema contém oito equações em que cada uma representa grupo de despesas

\footnotetext{
${ }^{9}$ Em ambas as eleições, os candidatos conseguiram ser reeleitos: Fernando Henrique em 1998 e Lula em 2006.

${ }^{10}$ A Lei de Responsabilidade Fiscal foi instituída em maio de 2000, enquanto que as leis orçamentárias anuais são aprovadas sempre no segundo semestre de cada ano, para vigência no período seguinte. Sendo assim, optou-se por considerar o efeito da LRF a partir das execuções orçamentárias de 2001.

${ }^{11}$ Dos 57 parâmetros de interação "LRFxCiclos", apenas 15 foram estatisticamente significativos. Além disso, com a inclusão dessas dummies, o $\mathrm{n}^{\circ}$ de parâmetros significativos da dummy LRF se reduziu de 12 para 3 , no total de 19 parâmetros.

${ }^{12}$ Os resultados para essas especificações poderão ser disponibilizados, mediante solicitação aos autores.
} 
orçamentárias classificadas pela ótica da natureza econômica; o segundo sistema contém seis equações, cada uma representando despesas classificadas pela ótica funcional; o terceiro sistema é formado por cinco equações, representando grupos de receitas orçamentárias classificadas pela natureza econômica.

\subsection{Fonte e natureza dos dados utilizados}

Os dados que se referem às execuções orçamentárias do governo federal (orçamento fiscal e da seguridade social) no período de 1985 a 2010, foram extraídos dos relatórios publicados pela Secretaria do Tesouro Nacional - STN, os quais tiveram seus valores devidamente atualizados para dezembro de 2010, pelo Índice Geral de Preços - Disponibilidade Interna da Fundação Getúlio Vargas. Todas as séries foram transformadas pelos logaritmos naturais de seus valores per capita.

No que tange às despesas orçamentárias, foram utilizados os seguintes grupos classificados por categorias econômicas: a) Pertencentes à "Despesa Corrente": despesa com "Pessoal e Encargos Sociais", "Despesa com Juros e Encargos da Dívida" e "Transferências da União para Estados, DF e Municípios"; b) Pertencentes à "Despesa de Capital": "Amortização da Dívida" e "Investimentos"; e c) "Despesa Corrente", "Despesa de Capital" e "Despesa Total". Também foram consideradas as seguintes despesas classificadas sob a ótica funcional: "Defesa Nacional e Segurança", "Educação e Cultura", "Saúde e Saneamento", "Assistência e Previdência" e "Transporte" (como proxy dos dados relativos à infraestrutura).

Com a entrada em vigor da Portaria $\mathrm{n}^{\circ} 42$, de 14 de abril de 1999 , os gastos sob a ótica funcional foram reclassificados e ampliados de 16 para 28 funções. Para compatibilizar a nova classificação com a anterior, realizaram-se os seguintes reagrupamentos das despesas orçamentárias ocorridas a partir do ano de 2000: "Judiciária" (+ Essencial à Justiça e Direitos da Cidadania); "Administração e Planejamento" (+ Encargos Especiais); "Agricultura" (+ Organização Agrária); "Educação e Cultura" (+ Desporto e Lazer); "Indústria, Comércio e Serviços" (+ Ciência e Tecnologia); e "Saúde e Saneamento" (+ Gestão Ambiental).

Ainda, na ótica funcional das despesas, optou-se por considerar outro agregado de despesa, aqui denominado "Setor Produtivo", composta pelas funções "Agricultura" e "Indústria, Comércio e Serviços". A intenção de incluí-la decorre da hipótese de que os governos alteram a composição dos gastos públicos nos períodos eleitorais, visando não apenas demonstrar competência para a grande massa da população, como também por se importarem em atender aos interesses dos grandes grupos de empresários que dominam o setor produtivo do país, os quais, aliás, são responsáveis por empregar boa parte dos eleitores. Assim, teriam incentivos para expandirem os gastos nessa área, de forma a sinalizar uma possível prosperidade econômica nos períodos que antecedem as eleições.

No âmbito das receitas, analisou-se o comportamento da "Receita Corrente" e da "Receita de Capital" e suas respectivas subcategorias, "Receita Tributária" e "Operações de Crédito", além da própria "Receita Total". Por fim, a série do Produto Interno Bruto (PIB) per capita foi obtida diretamente do site do Instituto de Pesquisa Econômica Aplicada (IPEA). 


\section{Resultados e Discussões}

\subsection{Análises preliminares dos dados}

Inicialmente, no intuito de auxiliar na compreensão e discussão dos resultados econométricos, procedeu-se à estatística descritiva (Tabela 1) e à inspeção visual (Figura 1) das séries utilizadas nas estimações, de maneira a verificar o comportamento de suas oscilações anuais e o comportamento tendencial de longo prazo, para o período analisado.

Tabela 1: Estatística descritiva das séries anuais, no período 1985 a 2010, a preços de dezembro de 2010

\begin{tabular}{lrrrrr}
\hline Série & Média & $\begin{array}{l}\text { Desvio } \\
\text { Padrão }\end{array}$ & $\begin{array}{l}\text { Coeficiente } \\
\text { de Variação }\end{array}$ & \multicolumn{1}{c}{$\begin{array}{l}\text { Valor } \\
\text { Mínimo }\end{array}$} & \multicolumn{1}{c}{ Máor } \\
& & \multicolumn{1}{c}{ Mámo } \\
\hline Despesa Total & 6029,31 & 2175,98 & 36,09 & 1389,36 & 8956,86 \\
Despesa Corrente & 2952,08 & 962,96 & 32,62 & 1118,90 & 4682,52 \\
Pessoal e Encargos Sociais & 627,21 & 240,12 & 38,28 & 147,34 & 928,71 \\
Juros e Encargos da Dívida & 493,83 & 238,08 & 48,21 & 58,38 & 1013,73 \\
Transf. a Estados, DF e Muni- & 596,94 & 214,06 & 35,86 & 332,19 & 1029,02 \\
cípios & & & & & \\
Despesa de Capital & 3077,23 & 1454,81 & 47,28 & 270,46 & 5969,60 \\
Amortização da Dívida & 2602,45 & 1428,82 & 54,90 & 27,79 & 5564,97 \\
Investimentos & 123,48 & 42,11 & 34,10 & 52,98 & 222,75 \\
Defesa e Seg. Pública & 156,91 & 26,12 & 16,65 & 114,75 & 212,48 \\
Educação e Cultura & 180,49 & 55,04 & 30,50 & 112,07 & 275,63 \\
Saúde e Saneamento & 228,56 & 92,92 & 40,65 & 45,23 & 331,32 \\
Assistência e Previdência & 1091,63 & 515,58 & 47,23 & 181,59 & 2001,53 \\
Transporte & 88,55 & 74,86 & 84,54 & 25,03 & 267,76 \\
Setor Produtivo & 160,74 & 74,01 & 46,04 & 58,03 & 389,28 \\
Receita Total & 3021,93 & 1029,34 & 34,06 & 1421,53 & 4895,59 \\
Receita Corrente & 1089,40 & 176,40 & 16,19 & 771,92 & 1549,93 \\
Receita Tributária ${ }^{3}$ & 3339,59 & 1591,71 & 47,66 & 23,96 & 6248,94 \\
Receita Capital & 2856,07 & 1462,71 & 51,21 & 23,69 & 5421,31 \\
Operações de Crédito & 6361,52 & 2256,12 & 35,47 & 1436,50 & 9228,98 \\
Produto Interno Bruto & 16721,92 & 1595,92 & 9,54 & 14672,57 & 20868,05 \\
\hline Fonte: Fonte: Dados & & & & &
\end{tabular}

\footnotetext{
Fonte: Fonte: Dados da pesquisa.

${ }^{1}$ Todas as séries expressas em valores reais per capita.

2 É o desvio-padrão expresso em termos de percentual da média.

${ }^{3}$ As "Receitas de Contribuições foram incorporadas à conta da Receita tributária".
}

Corroborando a suspeita inicial obtida da estatística descritiva e da análise visual das séries utilizadas, detectou-se que todas elas são não estacionárias e integradas de primeira ordem, conforme os resultados dos testes de raiz unitária apresentados no Apêndice deste artigo (Tabelas A.1, A.2 e A.3).

Sendo assim, procedeu-se, à realização de testes de cointegração de Johansen para verificar a existência de relação de equilíbrio de longo prazo entre as variáveis de resposta $\left(Y_{t}\right)$ e o regressor $P I B_{t}$, e para evitar a estimação de regressões espúrias. Além dos testes de cointegração, outros testes foram realizados no sentido de averiguar a viabilidade e a robustez do modelo adotado: testes de heterocedasticidade e autocorrelação dos erros de cada equação, testes de endogeneidade do regressor $P I B_{t}$ e testes de correlação contemporânea entre os erros das equações do SUR. A Tabela 2, a seguir, apresenta a síntese dos resultados de cada um destes testes.

Dos resultados na Tabela 2, verifica-se que os testes não rejeitaram a hipótese de existência de cointegração entre o regressor $P I B_{t}$ e as variáveis de 


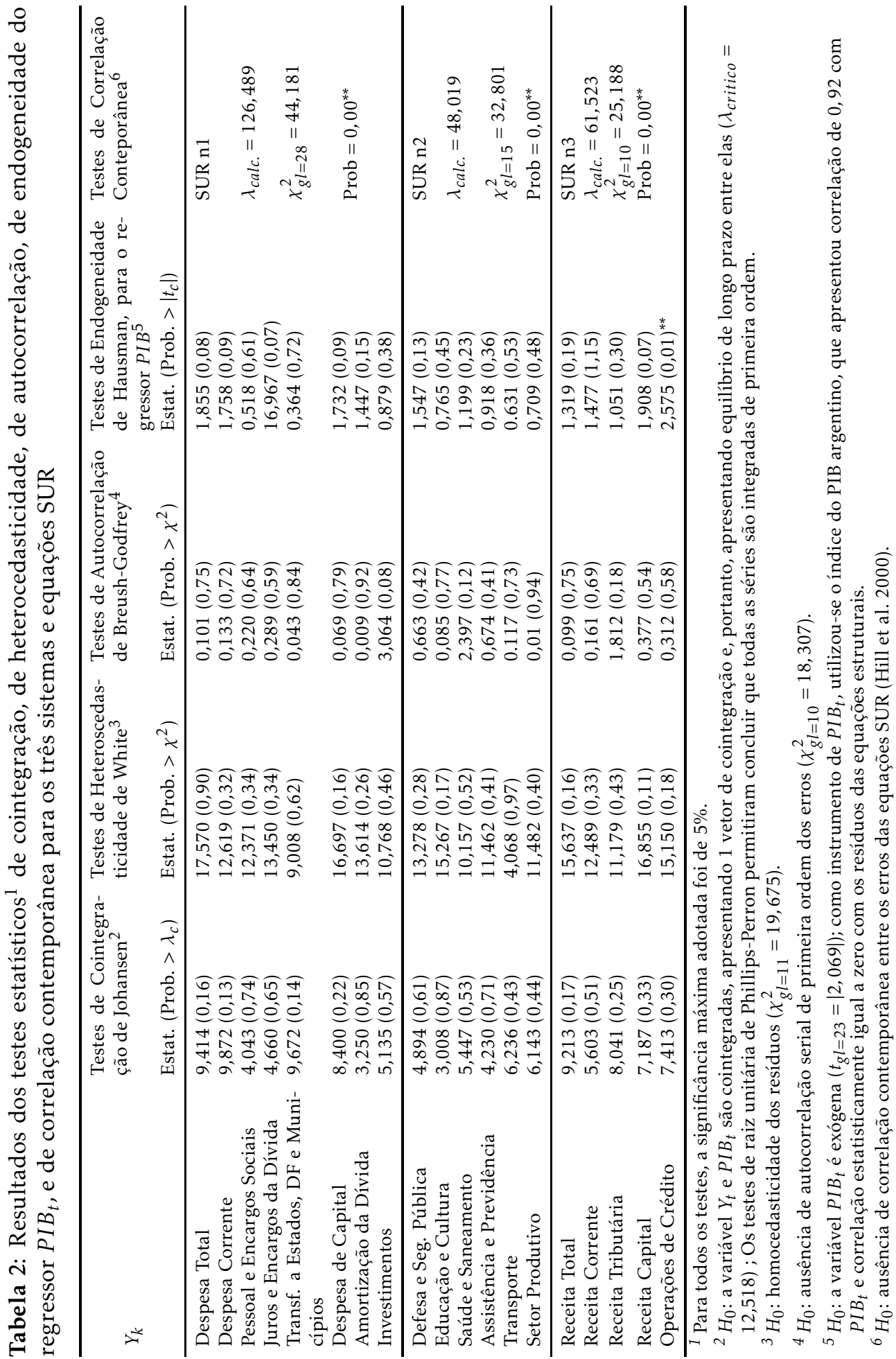



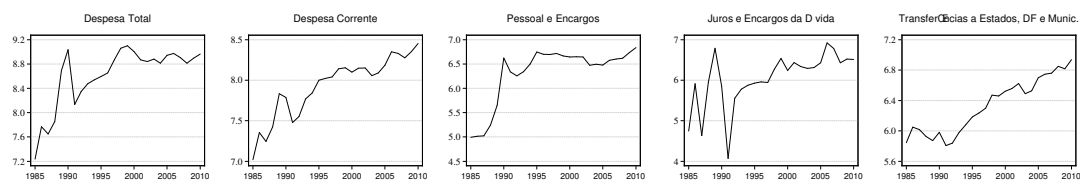

Despesade Capital

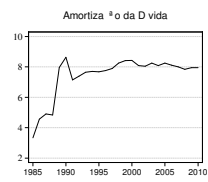

Investimentios
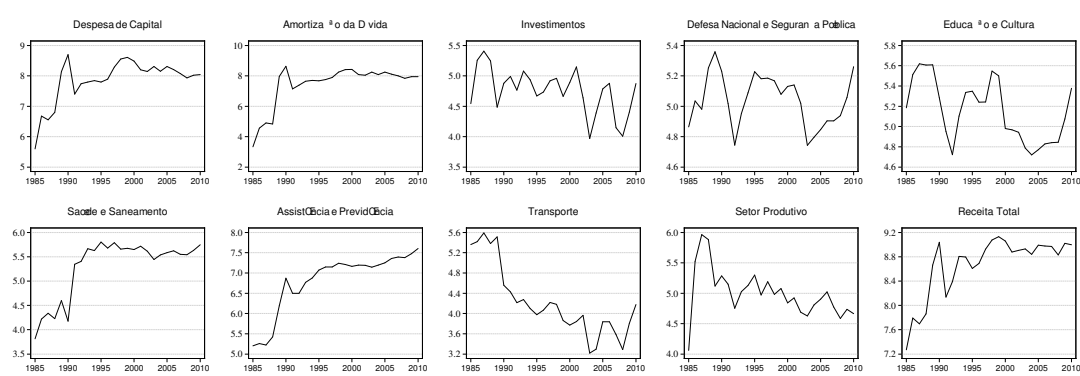

Setor Produ
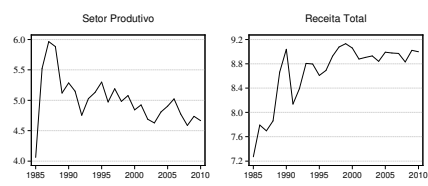

Receita Triburfat

Receitade Capital
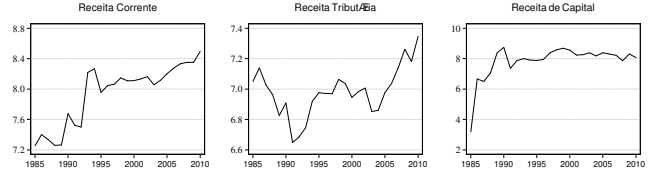

Opera tes de crostitio
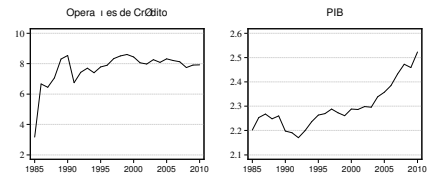

Fonte: Dados da pesquisa.

Figura 1: Gráfico das séries, em escala de seus logaritmos naturais - 1985 a 2010

resposta $\left(Y_{t}\right)$ das equações SUR, a 5\% de significância, o que leva a concluir a existência de relação de equilíbrio de longo prazo entre cada par de variáveis (segunda coluna). Os dois testes seguintes (terceira e quarta colunas) não rejeitaram as hipóteses de homocedasticidade e de ausência de autocorrelação serial de primeira ordem dos erros, a 5\% de significância, o que, caso contrário, poderia gerar estimadores viesados e tendenciosos.

No que tange aos testes de endogeneidade, não foi rejeitada a hipótese de que o regressor PIBt é exógeno, na sua relação com as variáveis $Y_{t}$ (penúltima coluna da Tabela 2). ${ }^{13}$ Exceção para a equação correspondente às "Operações de Crédito", no qual foi rejeitada a hipótese de que o regressor $P I B_{t}$ é exógeno, a 5\% de significância, o que poderia provocar viés e tendenciosidade dos parâmetros dessa equação. Em razão disso, procedeu-se com a aplicação do método de Mínimos Quadrados em Dois Estágios (MQ2E) dentro da metodologia do modelo SUR, onde, unicamente para a equação correspondente às "Operações de Crédito", os valores observados do regressor PIB $B_{t}$ foram substituídos pelos seus valores estimados (previstos). ${ }^{14}$

Por fim, os resultados da última coluna da Tabela 2, mostram que, para os três sistemas de equações considerados, os testes rejeitaram a hipótese de ausência de correlação contemporânea entre erros das equações, justificando, portanto, a utilização do modelo SUR. ${ }^{15}$

\footnotetext{
${ }^{13}$ Os testes de endogeneidade de Hausman foram realizados de forma conjunta, dentro da metodologia do SUR

${ }^{14} \mathrm{Na}$ aplicação do MQ2E, utilizou-se como instrumento de $P I B_{t}$ o índice do produto interno bruto da Argentina, que apresentou correlação de 0,92 com $P I B_{t}$ e correlação estatisticamente igual a zero com os resíduos das equações estruturais. A série do índice do PIB argentino foi obtida diretamente do site do IPEA.

${ }^{15}$ Detalhes deste teste podem ser encontrados em Hill et al. (2000).
} 
Nas próximas seções são apresentados os resultados econométricos do modelo SUR, divididos para cada um dos três sistemas de equações estimados neste estudo: despesas por grupo de natureza econômica, despesas pela ótica funcional e receitas por categoria econômica.

\subsection{Despesas por natureza econômica}

No que tange às despesas por natureza econômica, a Tabela 2 traz evidências de ciclos políticos orçamentários decorrentes do calendário eleitoral. Nos oito grupos de despesa considerados, os ciclos apresentaram configurações específicas quanto ao momento em que se deu o pico de aumento no gasto, corroborando a hipótese de execução fiscal voltada ao retorno eleitoral.

A "Despesa Total" a "Despesa Corrente" e a "Despesa de Capital" apresentam ciclos com forte aumento no ano eleitoral (32, 2\%, 20,4\% e 44,7\%, respectivamente), mas também com aumentos nos anos pós-eleitoral $(26,9 \%, 13,8 \%$ e $36,4 \%$, respectivamente), em relação ao ano-base (o segundo ano de mandato). ${ }^{16}$

Aparentemente, esses resultados estariam em sentido contrário à teoria convencional, que, de modo geral, prevê aumento do gasto no ano eleitoral, seguido de queda no ano seguinte, em virtude da consequente necessidade de ajuste fiscal. No entanto, pode-se contextualizar tais resultados, dada a provável influência das instituições brasileiras sobre o comportamento dos políticos. Van Dalen \& Swank (1996) e Ogura (2000) argumentam que certos gastos são acordados durante a campanha eleitoral e executados, de fato, no ano seguinte, o que justificaria os aumentos percebidos no primeiro ano dos mandatos. Além disso, algumas legislações impõem vedações para o aumento de determinadas despesas no período eleitoral, mas não alcançam o disposto em acordos e promessas de campanha e tampouco limitam a aprovação de algumas medidas em ano eleitoral que só começam a produzir impactos financeiros a partir do ano seguinte.

Para exemplificar, o art. 7, da Lei Eleitoral 9.504/1997, veda a concessão de reajustes ao funcionalismo público acima da inflação do ano eleitoral, nos 180 dias antes da realização das eleições. Enquanto que o art. 21 da LRF veda qualquer espécie de aumento na despesa com pessoal concedido nos 180 dias anteriores ao final do mandato. Dessa forma, os políticos ficam desimpedidos de aprovar, entre o início de abril até 30 de junho, reajustes programados para vigorar no primeiro ano do próximo mandato. Isso evidencia certo descompasso da LRF com a legislação eleitoral, e sustenta a discussão que Rogoff (1990) faz em relação a alterações no calendário eleitoral, de modo a dificultar mudanças oportunistas na política fiscal em pleno ano de eleição.

Mais adiante, será discutido que a "Despesa com Pessoal e Encargos Sociais" aumentou significativamente no período pós-eleitoral em relação ao anobase, ainda que em percentual menor do que o aumento percebido no ano eleitoral. Esse ciclo político específico pode ter relação com a existência de constrangimentos institucionais colocados para os anos eleitorais, de modo que, alternativamente, a manipulação da política fiscal passa a levar em conta seu efeito futuro, ou seja, comprometendo-se com gastos maiores para o ano

\footnotetext{
${ }^{16}$ A especificação logarítmica para a variável dependente implica que os coeficientes estimados devam ser interpretados em termos percentuais. De acordo com a Tabela 3, para a "Despesa Corrente", por exemplo, em anos eleitorais, ela é $20,4 \%$ maior, em relação ao ano-base ( $2^{\circ}$ ano do mandato).
} 


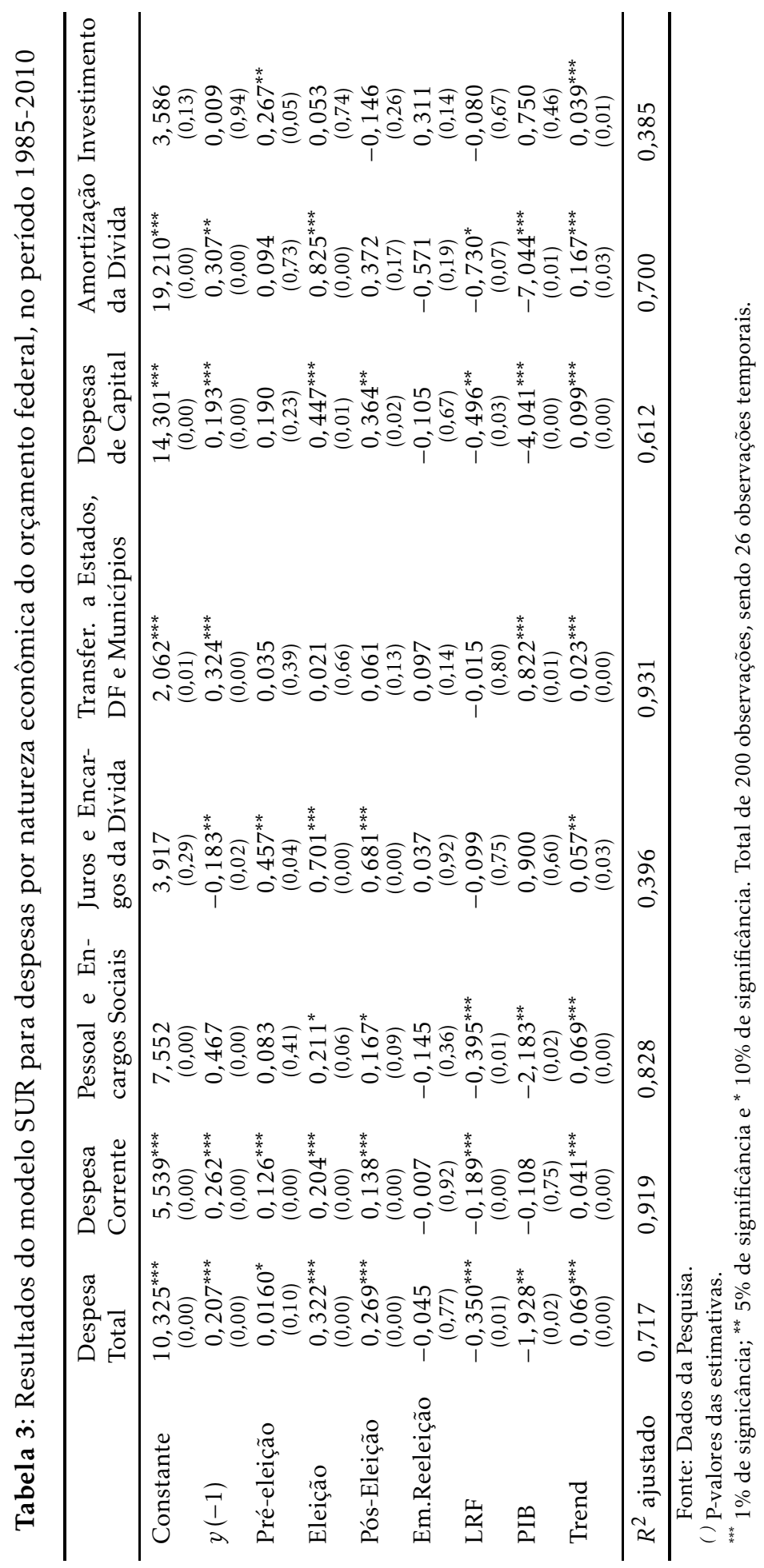


seguinte. De certa forma, isso confere com o resultado encontrado por Ogura (2000), também no âmbito das contas do governo federal, para essa mesma categoria de despesa, que evidenciou comportamento cíclico com pico no ano pós-eleitoral. Para chancelar tal resultado, Ogura (2000) assumiu como hipótese a definição de reajustes salariais para o funcionalismo público como compromisso de campanha, ou seja, prometidos no ano eleitoral, mas executados no ano seguinte.

Tanto a "Despesa Total" quanto a "Despesa Corrente", em sua maior parte composta por gastos vinculados à manutenção da máquina pública, não apresentaram comportamento de queda no período pré-eleitoral, certamente devido à maior rigidez desses gastos, destacada por Nakaguma \& Bender (2006). Nesse período, a "Despesa Corrente" se mostrou superior em relação ao anobase, o que corrobora o fato de que esta despesa não é facilmente ajustada para baixo, numa eventual tentativa de viabilizar poupança para gastos futuros.

As despesas relativas ao pagamento da dívida pública, "Juros e Encargos da Dívida" e "Amortização da Dívida", apresentaram ciclos com maior intensidade no ano eleitoral, de 70,1\% e 82,5\%, respectivamente. Porém, os gastos nos períodos pré e pós-eleitoral também se mantiveram altos em relação ao ano-base (embora no caso da "Amortização da Dívida", os coeficientes dos anos pré-eleitoral e pós-eleitoral sejam estatisticamente não significativos).

Os picos verificados para as despesas relacionadas à dívida pública não necessariamente está em confronto com a ideia do ciclo político eleitoral convencional, definido desde Nordhaus (1975). ${ }^{17}$ Todavia, há de se admitir que tal comportamento tenha sido afetado por outros fatores que impactaram o endividamento do governo federal, dentre os quais três elementos se destacam: (1) os acordos de refinanciamento de Estados e Municípios, (2) o reconhecimento e contabilização dos passivos contingentes, e (3) o programa de fortalecimento dos bancos federais (Rigolon \& Giambiagi 1999).

De fato, no período de análise ocorreram frequentes renegociações das dívidas das esferas infranacionais com o governo federal, com destaque para aquelas ocorridas nos anos de 1989 (Lei 7.976, de 27/12/89), 1993 (Lei 8.727, de 05/11/93) e 1997 (Lei 9497, de 11/09/97), que envolveram expressivo aporte financeiro e que coincidiram com períodos pré-eleitorais ou eleitorais. ${ }^{18}$ Dados apresentados por Nascimento \& Debus (2002), para o período entre 1994 e 2001, indicam que os programas de saneamento financeiro de Estados e Municípios (incluindo o saneamento dos bancos estaduais) foram responsáveis por $47,7 \%$ da evolução da dívida pública federal, enquanto que a contabilização dos passivos contingentes e o fortalecimento dos bancos públicos federais impactaram a evolução da dívida federal em $10,1 \%$ e $10,5 \%$ respectivamente.

No que tange às despesas com "Pessoal e Encargos Sociais", estas também apresentaram ciclo com gasto mais forte no ano eleitoral $(21,1 \%$ em relação ao ano-base). No pós-eleitoral, o gasto também aumenta, mas em percentual menor $(16,7 \%)$, enquanto o percentual de aumento no ano pré-eleitoral não se mostrou estatisticamente significativo. De modo geral, esses resultados retratam a rigidez nesse tipo de gasto, que dificilmente é passível de redução,

\footnotetext{
${ }^{17}$ Seguindo a concepção Nordhaus (1975), os ajustes fiscais ocorreriam nos anos pós-eleitorais, mediante volumes mais expressivos de pagamento da dívida contraída nos períodos que antecederam as eleições, com propósitos de manter ou expandir a atividade econômica naqueles períodos.

${ }^{18}$ Entre 1988 e 1997, houve sete acordos de negociação das dívidas entre o governo federal e os estados (Loureiro \& Abrúcio 2004).
} 
pois, ainda que não haja a concessão de reajustes, é natural se observar um crescimento vegetativo da folha salarial relativo à concessão de quinquênios, biênios ou outros benefícios adquiridos nos planos de carreiras de boa parte do funcionalismo público federal.

Por outro lado, os aumentos em anos eleitorais para as despesas com "Pessoal e Encargos Sociais" reforça a hipótese colocada por Rogoff (1990) de que a política fiscal é direcionada para gastos em itens mais visíveis e de benefício imediato ao eleitorado, diferentemente das despesas com investimento público, cujo prazo de maturação é maior e, logo, de visibilidade somente no longo prazo. No mesmo sentido, Tufte (1978), em estudo para 27 países democráticos, no período de 1961 a 1972, também havia constatado crescimento da renda disponível das famílias e crescimento econômico significativo no ano eleitoral.

Curiosamente, os resultados relativos a "Investimentos" também corroboram com essa hipótese de Rogoff (1990). Observa-se um aumento estatisticamente significativo, de $26,7 \%$, no ano pré-eleitoral, o que demonstra a necessidade de se investir com certa antecedência, de maneira que esse gasto só consegue produzir bens e serviços visíveis aos olhos do eleitor, no médio ou no longo prazo. Para os outros anos os parâmetros mostram-se estatisticamente não significativos, mas o coeficiente negativo encontrado para os anos pós-eleição está em consonância com a queda do investimento pós-eleitoral verificada por Nakaguma \& Bender (2006) nas contas estaduais. Percebe-se, claramente a preferência dos políticos em priorizar gastos que produzam efeitos mais visíveis para o eleitor no curto prazo em detrimento das políticas de desenvolvimento econômico, que necessitam de maior investimento para estabelecer um crescimento sustentável da economia.

As "Transferências da União para Estados, DF e Municípios" apresentam coeficientes positivos, conforme esperados, porém não significativos. A não significância desses coeficientes se coloca em sentido contrário à teoria convencional dos ciclos políticos eleitorais, que prevê aumento das transferências governamentais em razão da proximidade das eleições. ${ }^{19}$ Frey \& Schneider (1978) em análise para eleições presidenciais americanas no período de 1953 a 1975, já haviam detectado o aumento do gasto público com transferências para as famílias em ano eleitorais. No caso da não significância no ano eleitoral, podemos supor que o resultado sofre influência do disposto no art. $7^{\circ}$, da Lei Eleitoral 9.504/97, que veda a concessão de Transferências Voluntárias da União nos três meses que antecedem o pleito eleitoral. Carvalho (2009), em análise exclusiva desse tipo de transferência, também não identificou padrões de comportamento de ciclo político eleitoral, tanto no que se refere à celebração quanto à liberação de recursos de convênios entre União e Estados.

A possibilidade da reeleição presidencial, presente no modelo por meio da variável dummy "ER", não revela aumento de gasto em nenhum dos itens analisados, resultado confrontante ao encontrado por Nakaguma \& Bender (2006) no âmbito das eleições estaduais. ${ }^{20}$ Esses resultados não significativos referentes à Emenda à Reeleição sugerem que ela tem pouca ou mínima influência sobre os ciclos políticos orçamentários no âmbito federal. Dessa

\footnotetext{
${ }^{19}$ Conforme Tufte (1978) e Rogoff \& Silbert (1988).

${ }^{20}$ Nakaguma \& Bender (2006) identificaram aumento de 6,2\% das Despesas Correntes em função da possibilidade de reeleição. Os coeficientes dos demais itens (Despesa Total, Despesa de Custeio e Despesa de Capital), apesar de apresentarem sinal positivo, sugeriram aumento do gasto em função da oportunidade de reeleição.
} 
forma as programações fiscais com fins eleitoreiros estariam menos direcionadas à reeleição do político para o próximo mandato, mas mais direcionada à permanência do mesmo partido, a partir de sua coligação partidária, independentemente de qual figura política irá ocupar a cadeira da Presidência. ${ }^{21}$

A dummy correspondente à LRF é responsável por uma queda média de 35\% da "Despesa Total", 18,9\% da "Despesa Corrente", e 49,6\% das "Despesas de Capital", no período, em comparação ao ano-base. À semelhança do que foi constatado por Nakaguma \& Bender (2006) no âmbito dos estados (queda de 23,9\% nas Despesas de Capital) A redução percebida nas "Despesas de Capital" pode ser atribuída, em parte, à combinação de duas restrições advindas da LRF: (1) o fortalecimento da chamada "regra de ouro", ratificada em seu artigo 12; (2) a publicação da Resolução do Senado no 48, de 2007.

Conforme Ferreira Júnior (2007), a LRF teria tornado mais forte a chamada "Regra do Ouro", da Constituição Federal de 1988, cujo propósito é coibir o financiamento das despesas correntes, via operações de crédito. Segundo Nascimento \& Debus (2002) a Regra do Ouro, que consistia em matéria orçada no âmbito da Constituição de 1988 (o limite das operações de crédito é o montante destinado às despesas de capital e que estão previsto na Lei Orçamentária Anual), com o advento da LRF, também passa a ser matéria financeira.

No que tange à Resolução do Senado $\mathrm{n}^{\circ} 48$, de 2007, esta estabeleceu a limite de $60 \%$ da receita corrente líquida da União para realização de operações de crédito. Nesse caso, pode-se considerar que os efeitos combinados do fortalecimento da "regra de ouro" e da Resolução do Senado no 48/2007 acabam por explicar o parâmetro de - 49,6\% da dummy LRF, referente às "Despesas de Capital".

Cabe maior destaque para a LRF quanto às quedas verificadas nas despesas com "Pessoal e Encargos Sociais". Conforme Tabela 3, essas despesas tiveram reduções expressivas, da ordem de $39,5 \%$, a partir da vigência da LRF. Todavia, conforme anteriormente salientado, é parcimonioso conceder à dummy da LRF o papel de proxy de todas as outras mudanças institucionais relevantes para o ajuste fiscal e que tornaram-se mais amadurecidas a partir da implantação desta lei.

A LRF também responde por uma queda média de $73 \%$ na Despesa com "Amortização da Dívida". Remetendo-se à Figura 1, é possível perceber nítida redução dessa despesa a partir do período de instituição da LRF. Ocorre que a LRF não trata de limites absolutos, mas sim relativos. Se o estoque da dívida aumentar em $10 \%$ e a Receita Corrente Líquida aumentar na mesma proporção, a interferência da variável LRF seria zero neste exemplo. Ainda, na Figura 1 , percebe-se que a variável PIB apresenta tendência de crescimento mais expressiva no mesmo período pós-LRF. Para a esfera federal, é usual que o estoque da dívida seja mensurado em relação ao PIB, de maneira que, levando em conta o sinal negativo e estatisticamente significativo para o regressor PIB $(-7,044)$, na Tabela 3 , pode-se concluir que quanto maior o PIB, menor poderá ser o montante de despesa com "Amortização da Dívida" necessária para estabilizar a relação dívida/PIB.

À exceção dos efeitos sobre as despesas com "Pessoal e Encargos Sociais", os efeitos relativos à LRF sobre os demais grupos de despesa requerem algu-

\footnotetext{
${ }^{21}$ Importante também ressaltar que existem poucas observações relacionadas à dummy "ER", no período analisado, o que certamente comprometeu as significâncias dos parâmetros relacionados. Em duas eleições (1998 e 2006) houve a possibilidade de reeleição de um candidato à Presidência da República.
} 
mas ponderações. Esperava-se que a LRF, de modo geral, não trouxe mudanças significativas para os gastos públicos federais, uma vez que a legislação visa constranger mais fortemente a disposição orçamentária dos estados e municípios.

Todavia, é preciso ter cuidado ao creditar todo o peso dos coeficientes estimados a uma única normativa. Apesar de a LRF representar um marco importante na consolidação do compromisso da política macroeconômica com o ajuste e a austeridade fiscal, é importante ressaltar que várias outras normas foram criadas, ao longo de toda a década de 90, em prol do equilíbrio orçamentário. Desde 1994, o Brasil ingressou numa fase de estabilidade econômica, que mais tarde acabou direcionando também à tomada de medidas fiscais restritivas, tais como as metas de superávit primário, a própria autonomia dada ao Banco Central para o controle da política monetária, reformas no sistema previdenciário e acordos com o FMI, dentre outros (Ferreira Júnior 2007). Sendo assim, é parcimonioso conceder à dummy da LRF o papel de proxy de todas as outras mudanças institucionais relevantes para o ajuste fiscal e que tornaram-se mais amadurecidas a partir da LRF.

Com relação à variável de controle TREND, vale destacar que a mesma fornece uma aproximação da taxa de crescimento de cada grupo de despesas. A Tabela 3 evidencia que, com exceção dos "Investimentos", todos os demais grupos de despesa apresentaram tendência positiva de crescimento no período.

\subsection{Despesas por função}

No que se refere às despesas orçamentárias classificadas por função, a Tabela 4 mostra que o grupo de despesa em "Assistência e Previdência" apresentou pico de aumento de 29,6\% em anos de eleição. Sakurai (2009) e Nakaguma \& Bender (2006), em análise para as contas municipais e estaduais, respectivamente, também constataram significativa elevação de despesas com pico no ano eleitoral para a função de "Assistência e Previdência".

O grupo de despesa de "Educação e Cultura" também apresentou pico de aumento em anos de eleição, $29,8 \%$, enquanto no ano pré-eleitoral o aumento foi de $23,7 \%$, em relação ao ano-base. À semelhança do que identificamos para a esfera federal, no âmbito estadual, Nakaguma \& Bender (2006) verificaram um pico de aumento de 51,8\% nos gastos com "Educação e Cultura" no ano eleitoral. Por outro lado, para os municípios brasileiros, as estimações de Sakurai (2009) não permitiram qualquer conclusão a respeito de possível manipulação eleitoral sobre esse grupo de despesa.

Quanto ao comportamento desses dois grupos de despesa nos períodos pós-eleitorais, constata-se que, na "Educação e Cultura", o gasto aumentou na média $18,7 \%$ no primeiro ano dos mandatos federais, enquanto que na "Assistência e Previdência" os aumentos foram de 18,5\%. Este último resultado reforça a constatação de Nakaguma \& Bender (2006) de forte rigidez nos gastos relativos à "Assistência e Previdência". ${ }^{22}$ Qualquer semelhança do comportamento rígido desses gastos pós-eleição com a Despesa Corrente e, mais especificamente, com a despesa com "Pessoal e Encargos Sociais" não deve ser mera coincidência. ${ }^{23}$

\footnotetext{
${ }^{22}$ A rigidez constatada no ano pós-eleitoral foi estatisticamente significativa somente pelo método de estimadores de efeito fixo (FE). Pelo método generalizado dos momentos (GMM), o sinal do coeficiente foi positivo, porém estatisticamente não significativo.

${ }^{23}$ Sakurai (2009, p.57) já havia sugerido que funções como "Saúde e Saneamento", "Assistência
} 


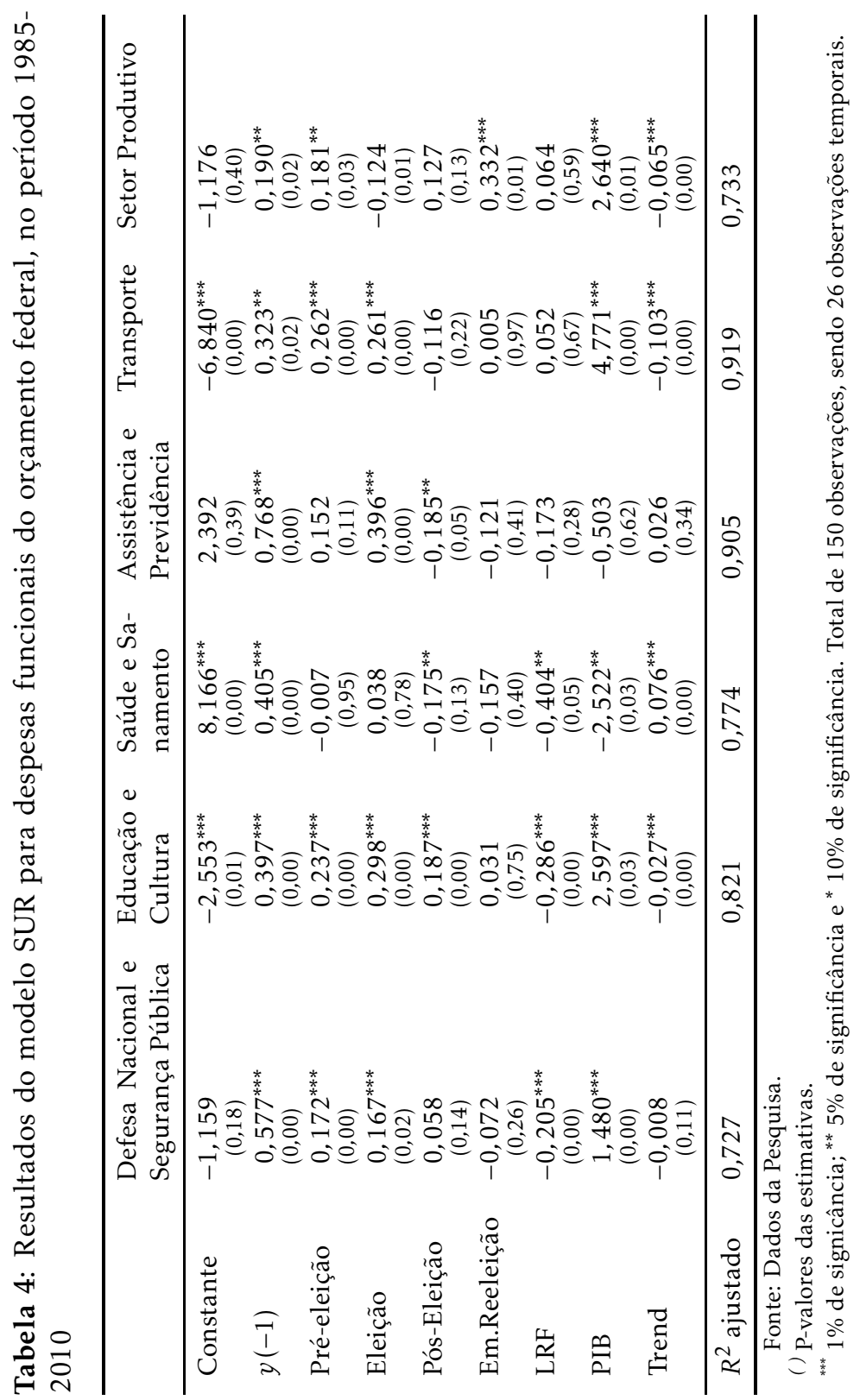


É sabido que boa parte das despesas com "Educação e Cultura" e "Assistência e Previdência" também está classificada como "Despesas Correntes", pelo critério da natureza econômica das despesas, que, por sua vez, são despesas que apresentam menor margem para reduções no curto e no médio prazo. No caso da "Educação e Cultura", trata-se de serviços intensivos em recursos humanos, além de abranger parcela relevante do eleitorado. ${ }^{24}$

Com o advento da redemocratização brasileira, apesar de parte dos serviços de educação ter sido descentralizada para estados e municípios, é sabido que a União mantém um percentual representativo da sua receita dedicado ao desenvolvimento e à manutenção da educação, de forma a cumprir com o disposto no Art. 212 da Constituição Federal e com as próprias exigências do FUNDEB. ${ }^{25}$

Configuração parecida também ocorre nas despesas com "Assistência e Previdência", na medida em que aposentados e pensionistas vinculados à Previdência Básica têm se tornado parcela cada vez mais significativa do eleitorado, fortalecendo-se politicamente, o que colabora para intensificação das pressões por reajustes no momento político das eleições.

Quanto às demais áreas funcionais, a Tabela 3 evidencia maior amplitude das despesas nos anos pré-eleitorais. Em relação a "Nacional e Segurança pública", verifica-se aumentos médios de $17,2 \%$, em anos pré-eleitorais e de $16,7 \%$, em anos eleitorais, sendo que o aumento de 5, $8 \%$ no ano pós-eleitoral mostrou estatisticamente não significativo. A Segurança Pública é, sem dúvidas, uma das grandes preocupações da sociedade brasileira nos últimos anos. Nakaguma \& Bender (2006) não encontraram evidência de ciclos para esta função no âmbito estadual a partir do método de análise estatística principal que utilizaram. ${ }^{26}$ Por sua vez, Bittencourt \& Hillbrecht (2003) encontraram para a mesma esfera evidência de ciclo com pico de aumento no ano eleitoral.

No que se refere às despesas com a função "Transporte", estas aumentam em 26, 2\%, nos anos pré-eleitorais. Nos anos pós-eleitorais o coeficiente possui um sinal negativo (redução da despesa), porém o mesmo não é estatisticamente diferente de zero. Isso nos mostra que, como se esperava, e em sintonia com o exposto por Rogoff (1990), os picos nos anos pré-eleitorais revelam a necessidade de adiantar a execução deste gasto, haja vista seu prazo de maturação mais longo, necessário para produzir bens e serviços notadamente visíveis ao eleitor. Embora não significativa, a indicação de uma possível redução nos anos pós-eleitorais (ou pelo menos estagnação), a exemplo do que foi constatado para os estados brasileiros no trabalho de Nakaguma \& Bender (2006), reflete as características das despesas ligadas à infraestrutura, que são mais flexíveis e passíveis de corte, quando da necessidade da adoção de políticas de ajuste fiscal.

\footnotetext{
e Previdência" e "Educação e Cultura" são compostas, em sua maioria, por despesas de natureza corrente.

${ }^{24}$ De acordo com o estudo da UNESCO ("Professores do Brasil: impasses e desafios"), publicado em 2009, os professores representam a terceira maior categoria ocupacional do país.

${ }^{25}$ De acordo com informações do Portal do MEC, disponibilizado em março de 2011, o aporte de recursos do Governo Federal para o FUNDEB, de R\$ 2 bilhões em 2007, aumentou para R \$ 3,2 bilhões em 2008, aproximadamente R \$ 5,1 bilhões para 2009 e, a partir de 2010 , será de $10 \%$ da contribuição total de estados e municípios.

${ }^{26}$ Nakaguma \& Bender (2006) não encontraram evidências de ciclos para segurança pública pelo método generalizado dos momentos (GMM), mas somente pelo método de estimadores de efeito fixo (FE), com pico de aumento no ano eleitoral.
} 
Os resultados referentes às despesas no "Setor Produtivo" evidenciam ciclos com picos de aumentos médios de $18,1 \%$ nos anos pré-eleitorais. Isso pode estar refletindo programações orçamentárias para fins eleitorais, levando em conta atendimento de interesses dos diversos, tais como estímulo ao crescimento de curto prazo da economia e do nível de emprego, sem deixar de lado as inevitáveis licitações com grandes grupos empresariais do país, com o consequente apoio desses grupos produtivos, minando potenciais acordos desses grupos com a oposição.

O efeito da dummy da Emenda à Reeleição (ER) nas despesas do "Setor Produtivo" é de aumento médio de 33,2\% em virtude da possibilidade de reeleição de um candidato, o que talvez possa sugerir que o setor empresarial estabeleça, nas suas negociações, uma relação mais próxima com a figura do candidato à Presidência, em detrimento da coligação ou do partido.

Os demais resultados relativos à Emenda à Reeleição não demonstraram significância estatística e sequer convergência no que se refere ao sinal dos coeficientes. Nakaguma \& Bender (2006), utilizando a mesma dummy de Emenda à Reeleição em análise de cinco despesas funcionais dos estados brasileiro, somente obtiveram resultado estatisticamente significativo em uma delas, o que reforça a hipótese aqui formulada de que a emenda em si não é relevante para explicar as motivações políticas de reprogramação das despesas orçamentárias em período eleitoral, uma vez que os interesses que de fato orientam tais programações focam na manutenção de um partido ou de coligação no poder, e não de um político em específico.

No que diz respeito à LRF, ela respondeu por uma queda nos itens de despesa "Defesa Nacional e Segurança Pública", "Educação e Cultura" e "Saúde e Saneamento", em valores de 20,5\%, 28,6\% e 40,4\%, respectivamente. Esses resultados sugerem que os investimentos nessas funções foram prioritariamente cortados diante da necessidade de ajuste fiscal imposto pela LRF. Para as demais funções, os resultados não foram estatisticamente significativos.

Mais uma vez, a variável TREND nos evidencia as tendências de crescimento das despesas. Entre elas, destacamos a despesa com "Saúde e Saneamento", que apresenta aumentos da ordem de 7,6\% ao ano, e as despesas com o "Setor Produtivo" e "Transporte", que apresentam tendência de redução anual da ordem $6,5 \%$ e 10,3\% ao ano, respectivamente. Certamente, os efeitos da Emenda Constitucional no 29 explicam, em parte, o crescimento da tendência da despesa per capita com "Saúde e Saneamento", enquanto que as privatizações ocorridas ao longo do período, bem como o surgimento das Parcerias Público-Privadas (PPP's), estariam refletindo a queda tendencial das despesas com "Setor Produtivo" e "Transporte".

Para o item de despesa "Educação e Cultura" a variável TREND sinaliza tendência de queda nesse gasto de $2,7 \%$ ao ano. Isso pode representar a continuidade de uma política de descentralização na prestação de serviços educacionais iniciada com o advento da Constituição de 1988. Para os demais itens de despesa, os coeficientes da variável TREND não se mostraram estatisticamente significativos.

Como evidência geral, dentre as seis despesas funcionais apresentadas na Tabela 4, apenas "Saúde e Saneamento" não apresentou evidências de ciclos políticos orçamentários. Isso fortalece uma das hipóteses de Rogoff (1990) para o caso das eleições presidenciais no Brasil: ainda que os políticos não promovam um forte aumento no gasto público como um todo no período eleitoral, eles tentam manipular sua composição priorizando as áreas funcionais 
associadas a bens e serviços de maior visibilidade, preferência e facilidade de consumo ao eleitor. Há de se ponderar também que algumas instituições podem estar cumprindo o seu papel de restringir a execução de despesa em certas funções no ano eleitoral, induzindo os políticos a anteciparem parcelas dos gastos oportunistas dedicados a elas.

De fato, não era esperado que os resultados referentes a "Saúde e Saneamento" estivessem isentos de ciclos políticos orçamentários na esfera federal, haja vista que estão entre os principais serviços ofertados pelo setor público, especialmente a saúde, sempre alvo de polêmicas quanto sua efetividade e alcance sobre toda a população. Além disso, Bittencourt \& Hillbrecht (2003) e Nakaguma \& Bender (2006) já haviam diagnosticado uma significativa possibilidade de ciclos eleitorais para essa função no âmbito estadual. A descentralização da oferta dos serviços de saúde com o advento da Constituição de 1988 e o engessamento dos seus gastos, especialmente a partir da Emenda Constitucional 29, de 13 de setembro de 2000, que garantiu recursos mínimos à área, respondem, em parte, pela ausência de evidências cíclicas eleitorais no nível federal, para as despesas em "Saúde e Saneamento".

\subsection{Receitas por categoria econômica}

No que se refere às receitas orçamentárias classificadas por categoria e natureza econômica, a Tabela 5 evidencia, no geral, a existência de ciclos políticos orçamentários em todas as categorias de receitas analisadas. No entanto, assim como observado na análise para as despesas por natureza econômica, os padrões cíclicos são específicos para cada grupo, no que tange ao período em que os altos e baixos se manifestam.

A impressão que se tem sobre a análise das receitas é que a dinâmica da demanda por gastos dita o volume de receitas disponíveis por categoria econômica, haja vista que uma parte dessas receitas já possui gastos estritamente vinculados. Nakaguma \& Bender (2006), por exemplo, já haviam percebido um aumento endógeno da "Receita Tributária" nos anos eleitorais, decorrente da expansão econômica promovida pelo aumento dos gastos públicos neste período.

No caso da "Receita Total", percebe-se um forte crescimento ao longo de todo o ciclo político, com pico de aumento de $36,8 \%$ no ano eleitoral, e aumentos de $26,4 \%$ e $21,5 \%$, para os períodos pós-eleitoral e pré-eleitoral, respectivamente. Conforme pode ser visto na seção 4.2, tal ciclo é bastante parecido com o evidenciado para o item de "Despesa Total". Isso sugere que, embora haja impacto político no orçamento público, há uma busca pela manutenção do equilíbrio orçamentário intertemporal.

Para a "Receita Corrente" pode ser observado um comportamento parecido, com aumentos de 16,1\% no ano eleitoral e 13,4\% no ano pré-eleitoral. Embora estatisticamente não significativo, o coeficiente para o ano pós-eleitoral é positivo, $8,8 \%$. Retomando a seção 4.2 , também percebemos aumento da "Despesa Corrente" com pico no ano eleitoral.

Quanto à "Receita Tributária", uma mudança estatisticamente significativa ocorre nos anos pós-eleitorais, com o aumento de $8,8 \%$, em média. Certamente que, com o passar do ano eleitoral, o contexto conjuntural torna-se mais oportuno para adoção de políticas de aumentos de alíquotas e outras políticas pró-aumento da arrecadação, que trariam custos políticos danosos ao 


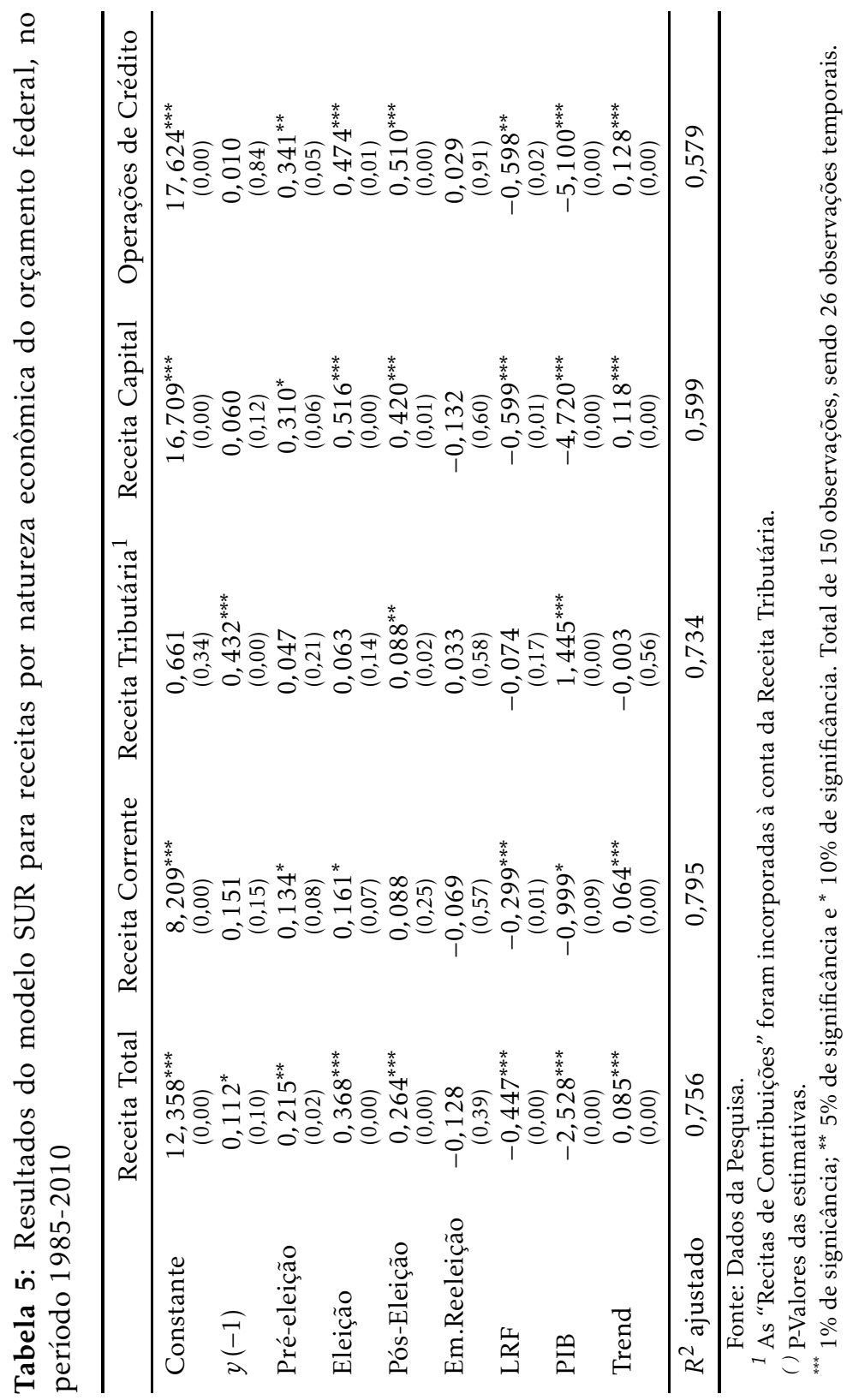


resultado eleitoral do mandatário, caso essas políticas fossem efetivadas na segunda metade do seu mandato.

Esse resultado também está de acordo com a teoria convencional, que prevê que o aumento dos impostos, quando necessário para cumprir com o equilíbrio orçamentário, se dá após o término das eleições, numa tentativa de evitar o desgaste com eleitor e perder votos. ${ }^{27}$ Rogoff \& Silbert (1988) esclarecem que os políticos, enquanto se veem impossibilitados politicamente de aumentar a arrecadação tributária, costumam apelar para a senhoriagem (emissão de moeda) ou a emissão de títulos para financiar o déficit. A consequência comum pós-eleição é um cenário de alta inflação e aumento da dívida.

No que tange à "Receita de Capital" percebe-se aumentos significativos nos anos de pré-eleição, eleição e pós-eleição, quando comparados ao anobase do mandato (segundo ano), da ordem de $31 \%, 51,6 \%$ e $42 \%$, respectivamente. Esses aumentos têm relação com o comportamento das receitas com "Operações de Crédito", que se mostram expressivamente maiores nos anos pré-eleitorais, eleitorais e pós-eleitorais, da ordem de 34,1\%, 47,4\% e 51,0\%, respectivamente. Numa interpretação análoga, pode-se afirmar que as "Operações de Crédito" são significativamente menores no segundo ano, quando comparados aos outros três anos do mandato.

Percebe que é justamente em anos pós-eleitorais que ocorre o maior aumento das "Operações de Crédito". A justificativa para esse pico no ano póseleitoral se coaduna com o questionamento feito em relação às análises dos resultados para a "Receita Total" e "Receita Tributária". Engessado pelos gastos futuros negociados durante o período eleitoral, no novo mandato, o governo se esbarra com os limites da economia, que impedem uma expansão ilimitada da arrecadação tributária, incorrendo a novos empréstimos, de modo a cumprir suas promessas de campanha.

Esse resultado é totalmente contrário ao exposto por Nakaguma \& Bender (2006) em análise para os estados brasileiros. Segundo esses autores, as operações de crédito sofrem queda significativa nos períodos pós-eleitorais em virtude dos repetidos ajustes fiscais necessários nesses períodos. Obviamente, os estados figuram numa situação fiscal muito mais delicada do que a União. Inclusive, são devedores dela. Portanto, é esperado que apresentem queda nas operações de crédito no período pós-eleitoral, de modo que o ajuste fiscal para eles é uma situação imprescindível, imposto pela própria União, a partir da renegociação da dívida ocorrida na década de 1990.

Quanto aos coeficientes relativos à Emenda à Reeleição (ERit), nenhum deles foi estatisticamente significativo, evidenciando que esta emenda não trouxe mudanças no comportamento dos grupos de receitas analisados.

No que diz respeito à variável dummy da LRF, a Tabela 5 mostra que, à exceção da "Receita Tributária", todos os seus coeficientes foram estatisticamente significativos, evidenciando que a lei de responsabilidade fiscal teve efeito redutor nas receitas médias, para todos os grupos de receita analisados. Certamente que várias das restrições normativas da LRF explicam tais constrangimentos, dentre as quais se destacam a imposição do limite de $60 \%$

\footnotetext{
${ }^{27}$ Não bastasse o corte anunciado pelo Ministro da Fazenda, Guido Mantega, de R $\$ 50$ bilhões no gasto público de 2011, pouco tempo após o término das eleições de 2010 para governador e presidente, as lideranças dos governos estaduais e federal já cogitaram a imediata criação de mais uma contribuição social para a saúde, em substituição à extinta CPMF. — Notícia obtida em reportagem publicada no dia 21/02/2011, no blog Radar Político, de autoria da jornalista Júlia Duailibi, do jornal "O Estado de São Paulo".
} 
da receita corrente líquida para realização das "Operações de Crédito"28 e o fortalecimento da "Regra do Ouro", que pretende coibir o financiamento de despesas correntes, via operação de crédito. De fato, percebe-se que as "Operações de Crédito" 29 e "Receita de Capital" foram as que mais sofreram impacto de redução após a LRF, da ordem de 59,8\% e 59,9\%, respectivamente.

Apesar do efeito redutor provocado pela LRF nas médias receitas, é necessário salientar o comportamento tendencial crescente para todos os grupos de analisados. De fato, a variável Trend, demonstra taxas de crescimento positivas para quase todos os itens de receita. Por isso mesmo, nota-se uma tendência de crescimento da "Receita Total" de, em média, 8, 5\% ao ano.

\section{Conclusões}

Pautado na teoria dos ciclos políticos orçamentários e utilizando o modelo econométrico apropriado, este estudo se propôs a evidenciar possíveis interferências de ordem político-eleitoral sobre a execução orçamentária da União no período de 1985 a 2010, levando em consideração também os efeitos de mudanças institucionais, como a Emenda à Reeleição e a LRF, sobre a amplitude dessas programações oportunistas.

Foi possível identificar relação entre o calendário eleitoral e as variações observadas em diversos grupos de despesa e receita pública da esfera federal, caracterizando a presença de ciclos políticos orçamentários na maioria das categorias de receitas e despesas analisadas.

Os resultados se coadunam com a teoria dos ciclos políticos eleitorais, ao sugerir que os policy makers são conhecedores da defasagem existente para realização de certos grupos gastos, de forma a realocá-los temporalmente de acordo com seu prazo de maturação, mas sempre visando maximizar os votos. Despesas que requerem maior prazo para se transformarem em bens e serviços disponíveis ao eleitorado ("Investimentos", "Transporte" e "Setor Produtivo") apresentam aumentos expressivos em anos pré-eleitorais, enquanto que despesas que são, em sua boa parte, correntes ("Assistência e Previdência" e "Pessoal e Encargos Sociais"), apresentam aumentos mais significativos nos anos eleitorais, justamente pelo seu efeito imediato aos olhos do eleitorado.

No que tange às receitas, os resultados corroboram a presença de ciclos políticos eleitorais. Os comportamentos cíclicos verificados seguem certa correspondência com o padrão de execução das despesas. No geral, ocorrem aumentos expressivos de receitas nos anos imediatamente pós-eleição, cujo contexto conjuntural é politicamente mais oportuno a tais aumentos, quando comparados aos anos próximos às eleições e ao próprio ano eleitoral.

Conclui-se que a política fiscal na esfera federal reflete um comportamento cíclico, orientado por interesses eleitorais. A diferença nos padrões cíclicos apresentados ajuda a entender melhor a maneira como o orçamento federal é programado. Espera-se que os resultados deste estudo possam servir de contribuição no processo de aprimoramento institucional, mediante conjugação

\footnotetext{
${ }^{28}$ Limite definido no inciso I do Art. $7^{\text {o }}$ da Resolução no 48/2007 do Senado Federal.

${ }^{29}$ A LRF procurou fazer cumprir a "Regra de Ouro" prevista no Artigo 167, inciso III da Constituição Federal de 1988, ao qual "É vedada a realização de operações de crédito que excedam as despesas de capital, ressalvadas as autorizadas mediante créditos suplementares ou especiais com finalidade precisa, aprovados pelo Poder Legislativo por maioria absoluta." Dessa forma, o que já era matéria orçamentária, a partir da LRF, passou a ser também matéria financeira (Nascimento \& Debus 2002).
} 
das legislações orçamentária e eleitoral que sejam promotoras de uma programação de longo prazo, voltada para o desenvolvimento social e econômico do país.

\section{Agradecimentos}

Os autores agradecem a Walter Belluzzo Jr. e a dois pareceristas anônimos pelos comentários e sugestões. Erros e omissões remanescentes são de responsabilidade exclusiva dos autores.

\section{Referências Bibliográficas}

Azevedo, S. (1997), 'Políticas públicas e governança em belo horizonte', Cadernos Ippur 1(2), 65-79.

Bittencourt, J. L. \& Hillbrecht, R. (2003), Ciclo político na economia brasileira: um teste para a execução orçamentária dos governos estaduais 1983/2000, in 'Anais do XXXI Encontro Nacional de Economia', Porto Seguro: Anpec.

Brender, A. \& Drazen, A. (2004), Political budget cycles in new versus established democracies, NBER Working Paper 10539.

Carvalho, A. R. E. S. F. (2009), 'Determinantes das transferências voluntárias da união aos estados brasileiros: uma análise quantitativa dos convênios celebrados entre os anos de 2003 a 2008'. Monografia (Graduação) - Fundação João Pinheiro - Belo Horizonte.

Coronel, A. C. \& Amorim, A. L.and Braga, M. J. C. A. C. (2010), 'Poder de mercado das exportações de farelo de soja: uma análise via demanda residual', Revista de Economia Contemporânea (Impresso) 14(3), 587-612.

Costa Júnior, N. C. A. \& Neves, M. B. E. (2000), 'Variáveis fundamentalistas e os retornos das ações', Revista Brasileira de Economia (Impresso) 54(1), 123137.

Drazem, A. \& Eslava, M. (2005), Electoral manipulation via expenditure composition: theory and evidence, NBER Working Papers 11085.

Fernandes, R. L. \& Giglio, R. F. Meuer, R. (2009), 'Existe comportamento diferenciado entre bancos públicos e privados em relação à política monetária?', Pesquisa em Debate 20, 97-111.

Ferreira Júnior, S. (2007), Desempenho fiscal e gestão pública nas esferas estaduais: uma avaliação das execuções orçamentárias no período de 1995 a 2004, in M. da Fazenda, S. do Tesouro Nacional \& E. de Administração Fazendária, eds, 'Finanças Públicas: XI Prêmio do Tesouro Nacional', Vol. 1, Universidade Federal de Brasília - UNB.

Ferreira Júnior, S. \& Teixeira, E. C. (2005), 'Relações de produção na pecuária leiteira: um estudo de caso das respostas da produção aos preços mensais', Revista de Economia e Agronegócio 3(2), 193-212. 
Frey, B. \& Schneider, F. (1978), 'An empirical study of politic-economic interaction in the united states', The Review of Economics and Statistics 60, 174183.

Greene, W. H. (1997), Econometric analysis, 3 edn, Prentice hall, New Jersey.

Griffths, W. E., Hill, R. C. \& Judge, G. (1993), Learning and practicing econometrics, John Wiley \& Sons Inc, New York.

Hibbs Júnior, D. A. (1977), 'Political parties and macroeconomic policy', American Political Science Review 71(4), 1467-1487.

Hill, R. C., Griffths, W. E. \& Judge, G. G. (2000), Econometria, Saraiva, São Paulo.

Loureiro, M. R. \& Abrúcio, F. L. (2004), 'Política e reformas fiscais no brasil recente', Revista de Economia Política 24(1), 50-72.

Nakaguma, M. Y. \& Bender, S. A. (2006), 'A emenda da reeleição e a lei de responsabilidade fiscal: Impactos sobre ciclos políticos e performance fiscal dos estados (1986-2002)', Revista de Economia Aplicada 10(3), 377-397.

Nascimento, E. R. N. \& Debus, I. (2002), 'Entendendo a lei de responsabilidade fiscal. 2.ed.', Brasília: Secretaria do Tesouro Nacional.

URL: Disponivel em: <http://www3.tesouro.gov.br/hp/downloads/EntendendoLRF.pdf>. Acesso em 10 Nov. 2012.

Nordhaus, W. (1975), 'The political business cycle', Review of Economic Studies 42, 169-190.

Novaes, L. M. (2007), O efeito da reeleição em gastos de saúde: uma análise do modelo de reputação política, Dissertação (mestrado), Escola de Economia de São Paulo da Fundação Getúlio Vargas, São Paulo.

Ogura, L. M. (2000), Ciclos eleitorais: Uma aplicação para a economia brasileira, Dissertação (mestrado em economia, Universidade de Brasília, Instituto de Ciências Humanas, Departamento de Economia, Brasília.

Queiroz, M. C. L. (2009), Ciclos políticos orçamentários no estado do ceará, 1986-2006, Dissertação (mestrado em economia), Universidade Federal do Ceará, Fortaleza.

Rigolon, F. \& Giambiagi, F. (1999), A renegociação das dívidas e o regime fiscal dos estados, Texto para discussão 69, BNDES, Rio de Janeiro.

Rogoff, K. (1990), 'Equilibrium political budget cycles', Review of Economic Studies 80, 21-36.

Rogoff, K. \& Silbert, A. (1988), 'Elections and macroeconomic policy cycles', Review of Economic Studies (55), 1-16.

Sakurai, S. N. (2009), 'Ciclos políticos nas funções orçamentárias dos municípios brasileiros: Uma análise para o período 1990-2005 via dados em painel', Estudos Econômicos 39(1), 39-58. 
Salvato, M., Antunes, P., Araujo Jr, A., Shikida, C. \& Spolaor, H. (2008), 'Ciclos políticos: um estudo sobre a relação entre flutuações econômicas e calendário eleitoral no brasil', Revista de Economia e Administração 7, 1-20.

Sargent, T. J. \& Wallace, N. (1975), 'Rational expectations, the optimal monetary instrument, and the optimal money supply rule', Journal of Political Economy (83), 241-254.

Shi, M. \& Svensson, J. (2006), 'Political budget cycles: Do they differ across countries and why?', Journal of Public Economics (90), 1367-1389.

Streb, J. M., Lema, D. \& Torrens, G. (2009), 'Checks and balances on political budget cycles: Cross-country evidence', Kyklos 62(3), 426-447.

Tufte, E. R. (1978), Politic control of the economy, Princeton University Press, Princeton, Nova Jersey.

Van Dalen, H. P. \& Swank, O. H. (1996), 'Government spending cycles: Ideological or opportunistic?', Public Choice 89, 183-200.

Veiga, L. \& Veiga, F. (2007), 'Political business cycles at the municipal level', Public Choice 131, 45-64.

Wooldridge, J. (2002), Econometric Analysis of Cross Section and Panel Data, Cambridge: MIT Press.

\section{Apêndice A}

Tabela A.1: Resultados dos testes de raiz unitária de Phillips-Perron ${ }^{1}$, para as séries de despesas classificadas pela natureza econômica

\begin{tabular}{lrrrr}
\hline \multirow{2}{*}{ Série $^{2}$} & \multicolumn{2}{c}{ Em Nível } & \multicolumn{2}{c}{ Na 1 ${ }^{\text {a diferença }}$} \\
\cline { 2 - 5 } & $t$ ajustado & Prob. & $t$ ajustado & Prob. \\
\hline Despesa Total & 1,417 & 0,957 & $-5,505$ & 0,000 \\
Despesa Corrente & 3,491 & 0,999 & $-4,813$ & 0,000 \\
Pessoal e Encargos Sociais & $-1,765$ & 0,691 & $-4,501$ & 0,008 \\
Juros e Encargos da Dívida & 1,086 & 0,920 & $-11,377$ & 0,000 \\
Transf. a Estados, DF e Municípios & $-2,188$ & 0,475 & $-5,606$ & 0,000 \\
Despesa de Capital & 0,898 & 0,896 & $-6,139$ & 0,000 \\
Amortização da Dívida & 0,646 & 0,849 & $-4,841$ & 0,000 \\
Investimentos & 0,505 & 0,817 & $-7,019$ & 0,000 \\
\hline Fonte: Dados da pesquisa. & & & & \\
${ }^{1} H_{o}$ : A série apresenta uma raíz unitária. & & & & \\
${ }^{2}$ Logaritmo natural dos valores per capita. & & & &
\end{tabular}


Tabela A.2: Resultados dos testes de raiz unitária de Phillips-Perron ${ }^{1}$, para as séries de despesas classificadas por função

\begin{tabular}{lcccc}
\hline \multirow{2}{*}{ Série $^{2}$} & \multicolumn{2}{c}{ Em Nível } & \multicolumn{2}{c}{ Na 1a diferença } \\
\cline { 2 - 5 } & $t$ ajustado & Prob. & $t$ ajustado & Prob. \\
\hline Defesa Nacional e Segurança Pública & 0,481 & 0,812 & $-3,708$ & 0,000 \\
Educação e Cultura & 0,053 & 0,691 & $-3,409$ & 0,002 \\
Saúde e Saneamento & 1,264 & 0,943 & $-6,567$ & 0,000 \\
Assistência e Previdência & 1,860 & 0,982 & $-3,270$ & 0,002 \\
Transporte & $-1,186$ & 0,201 & $-4,626$ & 0,000 \\
Setor Produtivo & 0,060 & 0,693 & $-10,025$ & 0,000 \\
\hline
\end{tabular}

Fonte: Dados da pesquisa.

${ }^{1} H_{o}$ : A série apresenta uma raíz unitária.

${ }^{2}$ Logaritmo natural dos valores per capita.

Tabela A.3: Resultados dos testes de raiz unitária de PhillipsPerron $^{1}$, para as séries de despesas classificadas pela natureza econômica e para o PIB

\begin{tabular}{|c|c|c|c|c|}
\hline \multirow{2}{*}{ Série $^{2}$} & \multicolumn{2}{|c|}{ Em Nível } & \multicolumn{2}{|c|}{$\mathrm{Na} 1^{\text {a }}$ diferença } \\
\hline & $t$ ajustado & Prob. & $t$ ajustado & Prob. \\
\hline $\operatorname{Rec}$ & 1,487 & 0,962 & $-5,555$ & 0,000 \\
\hline Receita Corrente & 2,793 & 0,998 & $-5,245$ & 0,000 \\
\hline Receita Trbutária ${ }^{3}$ & 0,558 & 0,830 & $-4,938$ & 0,000 \\
\hline Receita Capital & 0,596 & 0,839 & $-11,404$ & 0,000 \\
\hline Operações de Crédito & 0,578 & 0,834 & $-11,427$ & 0,000 \\
\hline Produto Interno Bruto & 2,068 & 0,988 & $-3,778$ & 0,001 \\
\hline
\end{tabular}

Fonte: Dados da pesquisa.

${ }^{1} H_{o}$ : A série apresenta uma raíz unitária.

${ }^{2}$ Logaritmo natural dos valores per capita.

3 As "Receitas de Contribuições" foram incorporadas à conta da Receita Tributária. 